\title{
Genomic insights into plant growth promoting rhizobia capable of enhancing soybean germination under drought stress
}

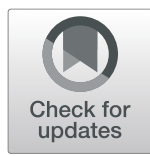

Nicholas O. Igiehon, Olubukola O. Babalola* (D) and Bukola R. Aremu

\begin{abstract}
Background: The role of soil microorganisms in plant growth, nutrient utilization, drought tolerance as well as biocontrol activity cannot be over-emphasized, especially in this era when food crisis is a global challenge. This research was therefore designed to gain genomic insights into plant growth promoting (PGP) Rhizobium species capable of enhancing soybean (Glycine max L.) seeds germination under drought condition.

Results: Rhizobium sp. strain R1, Rhizobium tropici strain R2, Rhizobium cellulosilyticum strain R3, Rhizobium taibaishanense strain R4 and Ensifer meliloti strain R5 were found to possess the entire PGP traits tested. Specifically, these rhizobial strains were able to solubilize phosphate, produce exopolysaccharide (EPS), 1-aminocyclopropane-1carboxylate (ACC), siderophore and indole-acetic-acid (IAA). These strains also survived and grew at a temperature of $45^{\circ} \mathrm{C}$ and in an acidic condition with a pH 4. Consequently, all the Rhizobium strains enhanced the germination of soybean seeds (PAN 1532 R) under drought condition imposed by $4 \%$ poly-ethylene glycol (PEG); nevertheless, Rhizobium sp. strain R1 and R. cellulosilyticum strain R3 inoculations were able to improve seeds germination more than R2, R4 and R5 strains. Thus, genomic insights into Rhizobium sp. strain R1 and R. cellulosilyticum strain R3 revealed the presence of some genes with their respective proteins involved in symbiotic establishment, nitrogen fixation, drought tolerance and plant growth promotion. In particular, exoX, htrA, Nif, nodA, eptA, IAA and siderophore-producing genes were found in the two rhizobial strains.

Conclusions: Therefore, the availability of the whole genome sequences of R1 and R3 strains may further be exploited to comprehend the interaction of drought tolerant rhizobia with soybean and other legumes and the PGP ability of these rhizobial strains can also be harnessed for biotechnological application in the field especially in semiarid and arid regions of the globe.
\end{abstract}

Keywords: Drought stress, Nitrogen fixation, PGP, Symbiotic establishment, Soybean, Whole genome sequences

\section{Background}

The symbiotic interaction between leguminous plants and nitrogen $(\mathrm{N})$ fixing bacteria, generally called rhizobia, has been the focus of research for over 12 decades. Recently, 'a renewed interest' in this area of research has been noticed due to its importance in sustainable agriculture, minimizing cost for the agriculturalists, enhancing soil fertility, alleviation of greenhouse-gas emissions [1] and improving plant's tolerance to drought stress [2].

* Correspondence: olubukola.babalola@nwu.ac.za

Food Security and Safety Niche, Faculty of Natural and Agricultural Sciences,

Private Mail Bag X2046, North-West University, Mmabatho 2735, South Africa
In addition, the role of soil microorganisms in plant growth, nutrient utilization, drought tolerance as well as biocontrol activity is well known and these beneficial microorganisms inhabit the plant rhizosphere. In the rhizosphere, these microorganisms promote plant growth via 'direct and indirect mechanisms' [3]. Additionally, the role of these beneficial microorganisms in biotic and abiotic stresses is gaining relevance and the mechanisms by which they enhance plant tolerance to drought include: Production of ACC deaminase to minimize the quantity of ethylene produced in the roots, microbial exopolysaccharide (EPS), induced systemic resistance and phytohormones production such as indole-3-acetic acid (IAA) [4-7].

(c) The Author(s). 2019 Open Access This article is distributed under the terms of the Creative Commons Attribution 4.0 International License (http://creativecommons.org/licenses/by/4.0/), which permits unrestricted use, distribution, and 
Indeed, plant growth can be regulated by ethylene $\left(\mathrm{C}_{2} \mathrm{H}_{4}\right)$ contents and the biosynthesis of this compound is regulated by biotic and abiotic stressors [8]. In the synthetic pathway of $\mathrm{C}_{2} \mathrm{H}_{4}$ in plants, $\mathrm{S}$-adenosyl methionine (S-AdoMet) is transformed to the immediate precursor of $\mathrm{C}_{2} \mathrm{H}_{4}$ 1aminocyclopropane-1-carboxylate (ACC) by aminocyclopropane-1-carboxylate synthase (ACS). Under drought stress conditions, plant homeostasis is regulated by $\mathrm{C}_{2} \mathrm{H}_{4}$ leading to decrease in shoot and root growth and even seed germination. Plant ACC is confiscated and disintegrated by ACC deaminase-producing rhizobia to release and supply energy and nitrogen. Thus, the disintegration and consequential removal of ACC by rhizobia alleviate the effects of $\mathrm{C}_{2} \mathrm{H}_{4}$, thereby minimizing plant stress and enhancing plant growth [9]. Therefore single and dual inoculation of plants with ACC-producing rhizobia can result in improved seed germination even under drought stress conditions. In particular, dual inoculation of ACC deaminase producing Pseudomonas and Bacillus with Mesorhizobium ciceri enhanced seed germination, shoot height, root length and seedling fresh weight of chickpea grown under stressed condition when compared to non-inoculated plants [10].

In addition, drought stress affects water availability to plant and water availability regulates the production and utilization of polysaccharides by rhizobia [11]. Example of such polysaccharides is exopolysaccharide (EPS) and production of EPS by rhizobia protects them from harsh conditions, which enhances their survival under such conditions. Amendment of wheat with EPS and catalase producing Rhizobium leguminosarum (LR-30), Rhizobium phaseoli (MR-2) and Mesorhizobium ciceri (CR-30 and CR-39) benefited the plant by improving its growth, drought tolerance index and biomass under drought condition using polyethylene glycol (PEG) 6000 as the drought factor. Thus, there is further need to X-ray the effects of new strains of Rhizobium on growth parameters (such as percentage seed germination) of other agricultural crops such as soybean (G. $\max$ L.) under drought condition stimulated by PEG.

Again, it has been reported that soil bacteria offer benefits to their host plants by suppressing plant pathogens and facilitating nutrient assimilation [4, 12, 13]. In our previous study [2], it was reported that some rhizobacteria mop up the insoluble form of iron from the soil environment and make it available to plants 'with the aid of siderophore' [14] and there is an evidence that some plants can use bacterial iron (III)-siderophore complexes for their growth [15] even though the phytorelevance of these complexes is controversial. On the other hand, the removal of iron from the soil by siderophore-producing rhizobia reduces the bioavailability of iron in the root region and consequentially suppresses the growth of fungal pathogens $[16,17]$.
Similarly, just like siderophore-producing bacteria, some rhizobia contribute to plant growth by helping to mineralize insoluble phosphate compounds to release phosphorus needed for plant growth [18]. Phosphorus in dicalcium phosphate, hydroxyapatite, rock phosphate and tricalcium phosphate in soil can be released by phosphate solubilizing bacteria such as Rhizobium, Bacillus, Burkholderia and Agrobacterium while other rhizospheric rhizobia have the ability to produce indole-acetic acid (IAA) which helps in root elongation and production of lateral roots and root hairs involved in nutrient absorption [19]. Elongation and increase in the number of root produced by plants as a result of IAA production can serve as a survival strategy to plants under drought stress condition and may even contribute in some other ways to plant development. It was reported by [20] that the increased production of IAA by Bradyrhizobium japonicum shows that, in addition to plant promotion, the bacterium could have other beneficial traits needed for plants (such as soybean) survival. In short, considering these benefits, the interaction between plants, especially legumes, and rhizobia is key to plant productivity.

Actually, rhizobia-legume symbiotic relationship commences with a molecular dialogue between the partners. The legumes produce flavonoids [21] that elicit the production of Nod factors (lipochitin oligosaccharides), that in turn, stimulate the development of root nodule [22]. Rhizobial species enter and colonize the root nodules where they metamorphose to bacteriods that fix atmospheric $\mathrm{N}$ [23]. Admittedly, other bacterial systems are involved in root colonization, efficient nodulation and $\mathrm{N}$-fixation, 'including surface polysaccharide and secretion systems' [1, 23, 24]. These processes in addition to PGP and drought tolerance ability of rhizobia are regulated by myriads of genetic components which can further be exploited to gain insights into legume -rhizobial interactions.

Therefore this study was designed to gain genomic insights into selected PGP rhizobia capable of promoting soybean seed germination under drought stress condition.

\section{Methods}

\section{Source of rhizobial species used in this study}

The rhizobial species used in this study were isolated from Bambara groundnut rhizospheric soil at North-West University campus (25.82080S: 025.61382E), Ngaka Modiri Molema District, Mahikeng, North-West Province, South Africa (Fig. 1) and the physicochemical analysis showed that the soil has the following properties: $7.65 \mathrm{pH}$, $1.62 \mathrm{mg} / \mathrm{kg} \mathrm{Fe}, 24.1 \mathrm{mg} / \mathrm{kg} \mathrm{Mn}, 1.06 \%$ organic carbon, $4.01 \%$ organic matter, $285 \mathrm{mg} / \mathrm{kg} \mathrm{K}, 397 \mathrm{mg} / \mathrm{kg} \mathrm{mg}$ and $0.066 \%$ total $\mathrm{N}$. The rhizobial species were sequenced by Sanger sequencing technique and identified in our previous study (National Centre for Biotechnology Information - NCBI - database) as Rhizobium sp. strain R1 (accession no. MG309875), Rhizobium tropici strain R2 (accession 


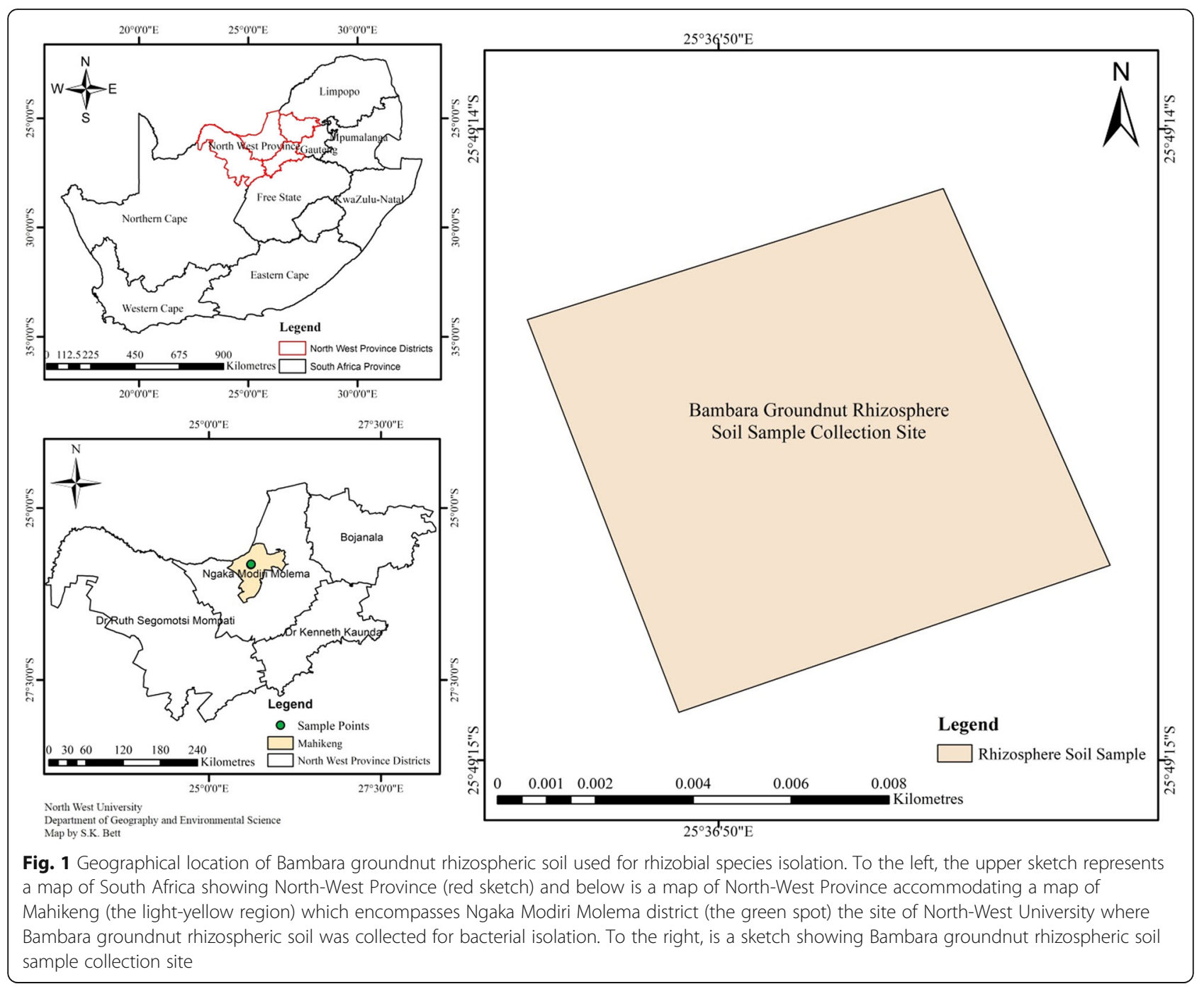

no. MG851722), Rhizobium cellulosilyticum strain R3 (accession no. MG309874), Rhizobium taibaishanense strain R4 (accession no. MG851723) and Ensifer meliloti strain R5 (accession no. MG851724).

\section{ACC deaminase quantification}

Rhizobial strains were grown in $5 \mathrm{ml}$ Luria Bertani (LB) at ambient temperature. Then ACC deaminase activity was determined according to method described by [25].

\section{EPS test}

First, rhizobial strains were qualitatively screened for exopolysaccharide production according to the method described by [26] with little modifications. Briefly, sterile Whatman filter paper discs $(6 \mathrm{~mm}$ in diameter) were aseptically placed in Petri dishes containing nutrient agar and $2 \mu \mathrm{l}$ of freshly grown cultures of each rhizobial species was directly inoculated on the surfaces of the discs in the plates. The nutrient agar used in this study was amended with $10 \%$ sucrose adjusted to $\mathrm{pH}$ of 5.5 and
7.5. Upon inoculation, plates were incubated at $28 \pm$ $2{ }^{\circ} \mathrm{C}, 37^{\circ} \mathrm{C}$ and $45^{\circ} \mathrm{C}$ for 7 days, 2 days and 1 day at the respective temperatures. Then, EPS production was evaluated on the basis of formation of mucoid colonies around the discs.

Alternatively, the quantity of EPS produced was determined according to the method described by [27] with little modifications. In summary, the four isolates were grown in nutrient broth amended with 5 and 10\% PEG 800 to induced drought stress as well as in nutrient broth lacking PEG 800 (0\% PEG). Cultures were incubated in a rotary incubator at room temperature for 4 days and were thereafter centrifuged to obtain the supernatant. Three milliliter $(3 \mathrm{ml})$ of cold absolute alcohol was mixed with $5 \mathrm{ml}$ of each rhizobial supernatant and incubated for $12 \mathrm{~h}$ at $4{ }^{\circ} \mathrm{C}$. Then EPS was gotten by centrifuging the cold alcohol-rhizobial supernatant mixture at $10000 \mathrm{rpm}$ for $15 \mathrm{~min}$ and the resultant supernatants were discarded. Then, the optical density of the EPS that settled at the bottom of the tubes were determined using a spectrophotometer (ThermoSpectronic, Merck) at $490 \mathrm{~nm}$. 


\section{Quantitative determination of siderophore produced by rhizobial species}

The quantitative determination of siderophore produced by rhizobial species was determined according to the method described by [28] with little modification. Briefly, freshly grown rhizobial species were inoculated into King B broth $\left(10 \mathrm{~g} / \mathrm{l}\right.$ glycerine, $20 \mathrm{~g} / \mathrm{l}$ peptone, $\left.1.5 \mathrm{~g} / \mathrm{l} \mathrm{MgSO}_{4}\right)$ and iron-free succinic acid broth $\left(6 \mathrm{~g} \mathrm{~K}_{2} \mathrm{HPO}_{4}, 3 \mathrm{~g}\right.$ $\mathrm{KH}_{2} \mathrm{PO}_{4}, 1 \mathrm{~g}\left(\mathrm{NH}_{4}\right)_{2} \mathrm{SO}_{4}, 0.2 \mathrm{~g} \mathrm{MgSO}_{4} \cdot 7 \mathrm{H}_{2} \mathrm{O}$ and $4 \mathrm{~g}$ succinic acid) in tubes, while controls were amended with chrome azurol S (CAS) solution and incubated at ambient temperature in a shaker incubator at $120 \mathrm{rpm}$. Rhizobial broths were centrifuged at $10000 \mathrm{rpm}$ for $10 \mathrm{~min}$. The quantity of siderophore was produced assessed by measuring the optical density of the supernatant at $400 \mathrm{~nm}$.

\section{Indole-acetic-acid (IAA) test}

Quantitative measurement of IAA produced by rhizobia species were determined according to the method described by [18] with little modification. In summary, each rhizobial strain was inoculated in 0.2 L LB broth and incubated in a rotary shaker at ambient temperature for $96 \mathrm{~h}$. One milliliter $(1 \mathrm{ml})$ of the rhizobial broth was centrifuged at $3000 \mathrm{rpm}$ for $30 \mathrm{~min}$, and thereafter, $2 \mathrm{ml}$ of the supernatant was mixed with 2 drops of orthophosphoric acid and $4 \mathrm{ml}$ Salkowski reagent. Optical density of the pink broth was taken at $530 \mathrm{~nm}$ using a spectrophotometer (ThermoSpectronic, Merck) and the actual concentration of IAA produced by the rhizobial species was estimated from a standard IAA curve in the range of $0-120 \mu \mathrm{g} / \mathrm{ml}$.

\section{Phosphate solubilization test}

Phosphate solubilization test was determined as described by [29] with little modification. Pikovskaya's agar with the following composition per litre was prepared: tricalcium phosphate $(5 \mathrm{~g})$, potassium chloride $(0.2 \mathrm{~g})$, magnesium sulphate $(0.1 \mathrm{~g})$, manganese sulphate $(0.0001 \mathrm{~g})$, yeast extract $(0.5 \mathrm{~g})$, glucose $(10 \mathrm{~g})$, agar $(15 \mathrm{~g})$, ammonia sulphate $(0.5 \mathrm{~g})$, ferrous sulphate $(0.001 \mathrm{~g})$, and the medium was autoclaved at $121^{\circ} \mathrm{C}$ for 15 min, after adjusting the $\mathrm{pH}$ of the final composition to $\mathrm{pH} 7.0$ using a pH meter. Autoclaved medium was poured on Petri dishes and allowed to solidify. Wells of $8 \mathrm{~mm}$ in diameter were made in the medium and inoculated with $25 \mu \mathrm{l}$ of broth culture of each isolates. Three (3) wells per isolate were used. Plates were incubated at $27^{\circ} \mathrm{C}$ for 4 days and a cleared zone around the wells indicated a positive result. Diameters of zones were obtained by measuring the diameter of zone of inhibition minus the diameter of the wells.

\section{Rhizobial growth response to different temperature}

LB broth was prepared according to the manufacturer's guidelines and autoclaved. Five $\mu \mathrm{l}$ of each rhizobial strain was inoculated in $25 \mathrm{ml}$ of LB broth and gently vortexed. Each rhizobial treatment was replicated 3 times for the different temperature. Inoculated broth was incubated at $28,35,45^{\circ} \mathrm{C}$. The O.D (optical density) of the rhizobial growths was taken using a spectrophotometer at $630 \mathrm{~nm}$ at days 4, 8, 12, 16 and 20.

\section{Rhizobial growth response to different $\mathrm{pH}$}

LB broth was prepared according to the manufacturer's guidelines and the $\mathrm{pH}$ of the broth was adjusted to acidic (4), neutral (7) and alkaline (10) $\mathrm{pH}$ and autoclaved. Five microliters of each rhizobial strain was inoculated in $25 \mathrm{ml}$ of LB broth and gently vortexed. Each rhizobial treatment was replicated 3 times. Inoculated broth was incubated at $28^{\circ} \mathrm{C}$. The OD of the rhizobial growths was taken using a spectrophotometer at $630 \mathrm{~nm}$ at days 5, 10, 15 and 20.

\section{Bacterial growth and preparation}

Three (3) of the rhizobial strains were selected for soybean inoculation. Rhizobial spp. were harvested as described by [30] with little modification. Freshly grown cultures of the rhizobial spp. were centrifuged at 5000 $\mathrm{rpm}$ for $300 \mathrm{~s}$ and the pellets were washed in $0.85 \%(\mathrm{w} /$ v) normal saline solution and thereafter homogenized in saline solution prior to solution.

\section{Seed germination test}

The colony counts of the rhizobial spp. were $20 \times 10^{5}$ CFU (colony forming unit) $\mathrm{ml}^{-1}$ (for R1 strain), $11 \times$ $10^{5} \mathrm{CFU} \mathrm{ml}^{-1}$ (for R3 strain) and $21 \times 10^{5} \mathrm{CFU} \mathrm{ml}^{-1}$ (for R5 strain). Rhizobial suspension $(0.5 \mathrm{ml})$ of each strain was pipetted into Petri dishes containing Whatman filter paper while $0.5 \mathrm{ml}$ of sterile distilled water was transferred to the non-inoculated (control) plates. Soybean seeds (PAN 1532 R) obtained from Agricultural Research Council, South Africa were surface sterilized in $75 \%$ alcohol and $1 \%$ sodium hypochlorite for $600 \mathrm{~s}$ and rinsed in sterile distilled water. Then 30 seeds were place in the Petri dishes containing inoculated filter papers and $4 \%$ PEG and the plates were gently swirled. Each treatment was done in triplicate. Parafilm paper was used to seal the plates incubated for 8 days in a growth chamber (GC-300TL, JEIO TECH, Korea) adjusted to 23/16 day/ night for periods of $8 / 16 \mathrm{~h}$ night/day at 10,000 light lux for 8 days. The number of germinated seeds was counted afterwards and the percentage seed germination rate was estimated using the following formula:

$$
\text { Percentage seed germination }(\%)=\frac{n}{\mathrm{~N}} \times 100
$$

Where $\mathrm{n}$ is the number of germinated seeds after 8 days and $\mathrm{N}$ is the total number of seeds. 


\section{Deoxyribonucleic acid (DNA) extraction for whole genome sequencing}

Fresh culture of Rhizobium sp. strain R1 and $R$. cellulosilyticum strain R3 was obtained by taking inocula from $50 \%$ glycerol and streaking on freshly prepared nutrient agar. Plates were incubated at $28^{\circ} \mathrm{C}$ for 4 days and thereafter bacterial DNA was extracted from the fresh isolates using Zymo DNA extraction kit following manufacturer's the instructions. The purity and concentration was determined by both 1\% agarose gel electrophoresis and a NanoDrop spectrophotometer. The DNA extracts were stored at $-20^{\circ} \mathrm{C}$ until use. Afterwards, $40 \mu$ l of DNA of extract of each bacterium was sent in an ice pack to Molecular Research Laboratory (Mr. DNA), Texas, USA for HiSeq system (illumina) sequencing.

\section{Sequencing, quality check, trimming and assembly}

Following the manufacturer's instructions, DNA libraries were made from 25 to $50 \mathrm{ng}$ of extracted DNA using KAPA HyperPlus kits (Roche). Upon library preparation, DNA concentration was determined using the Qubit ${ }^{\circ}$ dsDNA HS Assay Kit (Life Technologies) and average library size was evaluated using Agilent 2100 Bioanalyzer (Agilent Technologies). 'The workflow combines enzymatic steps and employs minimal bead-based cleanups'. DNA samples were enzymatically degraded into ds DNA fragments and thereafter end repair cum A-tailing were performed to obtain 'end-repaired, 5'-phosphorylated, 3'-dA-tailed ds DNA fragments.' Adapter ligation was performed by ligating ds DNA adapters with $3^{\prime}$-dTMP overhangs to $3^{\prime}$-dA-tailed DNA molecules, and thereafter, DNA libraries amplification were performed by using high fidelity and low-bias polymerase chain reaction (PCR). The DNA libraries were then assembled and diluted to $10.5 \mathrm{pM}$ and 'sequenced paired end for 500 cycles using the HiSeq system (Illumina).

Illumina data were extracted and uploaded into Kbase, reads quality was done by performing quality check of the illumina sequence using FastQC (v1.0.4) and low quality sequence and adapter were trimmed off using trimmomatic [31]. Illumina sequence reads were de novo assembled using both SPAdes and ARAST to create contigs.

\section{Annotation}

The genomes of R1 and R3 strains were annotated using Kbase Prokka (V1.12) annotation pipeline and rapid annotation using subsystem technology (RAST) server [32]. The aforementioned systems permit the identification of introns, functional annotations as well as 'manual curation of gene annotations'. They also possess platforms for metabolic construction with the aid of Kyoto encyclopedia of genes and genomes (KEGG) for comparing sequence using Basic Local Alignment Search Tool (BLAST) and functional comparisons using KEGG and/or FIGfam. The data for R1 and R3 were both given Bioproject number PRJNA496421 while R1 and R3 data were assigned Biosample numbers
SAMN10240937 and SAMN10245972 respectively upon submission to the GenBank database. In addition, R1 has SRA Accession number: SRR8060784 and R3 has SRA Accession number: SRR8061690.

\section{Statistical analyses}

Data obtained for the plant growth promoting and seed germination tests were analyzed using Microsoft Excel and Statistical Analysis System (SAS) platforms. Analysis of Variance (ANOVA) was performed for the data followed by Duncan test to determine differences between mean and $P<0.05$ was considered significant [33, 34]. With respect to sequenced data, mean read length and standard deviation of read length were computed using Kbase pipeline.

\section{Results}

Plant growth promoting traits of rhizobial species

In this present study, the plant growth promoting traits of rhizobial species were determined.

\section{Aminocyclopropane-1-carboxylate (ACC) production by rhizobial species}

With regard to ACC production, R5 strain produced the highest concentration of ACC followed by R1 strain while R2 strain produced the lowest concentration of ACC (Fig. 2a) under stress condition imposed by PEG. These rhizobial strains were further screened for other plant growth promoting traits such as EPS, siderophore production, IAA and phosphate solubilization tests.

\section{EPS production by rhizobial species}

In this study, all rhizobial species produced EPS. In particular, the rhizobial species incubated at $37^{\circ} \mathrm{C}$ produced EPS at pH 5.5 and 7.5 but R1 and R4 strains did not produce EPS when incubated at $45^{\circ} \mathrm{C}$ while $\mathrm{R} 2$ and $\mathrm{R} 3$ strains produced EPS under all the environmental conditions considered (Table 1). To be specific, among the rhizobial treatments, R1 strain produced the highest concentrations (0.7 and 0.6 O.D respectively) of EPS at 0 and $10 \%$ PEG concentrations and R2 produced the highest EPS at 5\% PEG concentration (Fig. 2b) followed by $\mathrm{R} 1$ and R3 strains.

\section{Siderophore production by rhizobial species}

The ability of rhizobial species to produce siderophore in different media (succinic acid broth and King B broth) showed that all the rhizobial species produced more siderophore in King B broth compared to succinic acid broth (Fig. 2c). R1 strain produced the highest concentration of 0.9 O.D in King B broth while R1 and R2 strains produced more siderophore than R4 and R5 strains in succinic acid broth (Fig. 2c). Conversely, the control treatments amended with CAS solution showed the lowest values for both media. 


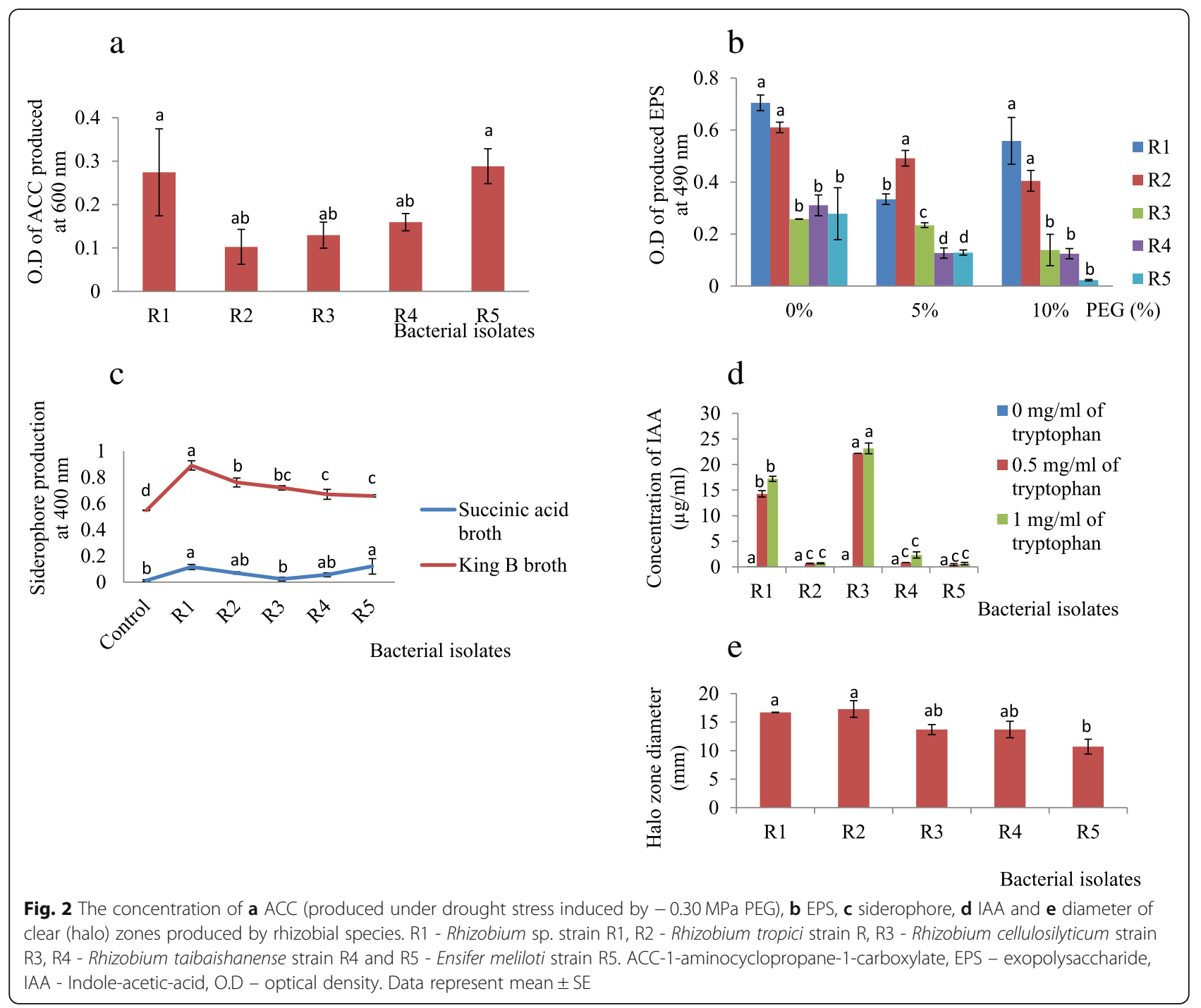

\section{IAA production by rhizobial species}

The ability of rhizobial species to produce IAA under different tryptophan concentrations revealed higher concentrations of IAA production by $\mathrm{R} 1$ and $\mathrm{R} 3$ strains. In particular, R3 strain produced the highest concentrations of IAA $(22.19$ and $23.155 \mu \mathrm{l})$ at 0.5 and $1 \mathrm{mg} / \mathrm{ml}$ of tryptophan respectively, followed by R1 strain, but the lowest concentrations were produced by $\mathrm{R} 5$ strain (Fig. 2d).

\section{Phosphate solubilization by rhizobial species}

As regards phosphate solubilization, R2 strain comparatively showed a bigger halo-zone in Pikovskaya's agar with a mean diameter of $17.3 \mathrm{~mm}$ while R1 strain showed a mean diameter of $16.7 \mathrm{~mm}$. The diameter of the halo-zone produced by $\mathrm{R} 5$ strain was lowest in this study (with a mean value of $10.7 \mathrm{~mm}$ ). Nevertheless, R3 and R4 strains produced halo zones with the same diameter $(13.7 \mathrm{~mm})$ (Fig. 2e).
Rhizobial growth response under environments with different temperatures

Considering the response of rhizobial species towards different environmental temperatures, we observed that $\mathrm{R} 1$ strain showed the highest growth at $28^{\circ} \mathrm{C}$ as depicted

Table 1 Qualitative response of bacteria towards exopolysaccharide (EPS) assay

\begin{tabular}{|c|c|c|c|c|c|c|}
\hline \multirow{2}{*}{$\begin{array}{l}\text { Bacterial } \\
\text { strain }\end{array}$} & \multicolumn{3}{|c|}{ Response at pH 5.5} & \multicolumn{3}{|c|}{ Response at pH 7.5} \\
\hline & $28^{\circ} \mathrm{C} \pm 2$ & $37^{\circ} \mathrm{C}$ & $45^{\circ} \mathrm{C}$ & $28^{\circ} \mathrm{C} \pm 2$ & $37^{\circ} \mathrm{C}$ & $45^{\circ} \mathrm{C}$ \\
\hline $\mathrm{R} 1$ & + & + & - & + & ++ & - \\
\hline $\mathrm{R} 2$ & + & ++ & + & + & ++ & ++ \\
\hline R3 & + & ++ & + & + & ++ & ++ \\
\hline R4 & + & ++ & - & + & ++ & ++ \\
\hline R5 & ND & ++ & + & $N D$ & + & ++ \\
\hline
\end{tabular}

Legend: $+=$ positive, $-=$ negative, $++=$ strongly positive, ND =Not determined, R1= Rhizobium sp. strain R1, R2 = Rhizobium tropici strain R2, R3 = Rhizobium cellulosilyticum strain R3, R4 = Rhizobium taibaishanense strain R4 and R5 = Ensifer meliloti strain R5 
by O.D values throughout the experimental period. However, at $45^{\circ} \mathrm{C}$, rhizobial growth response modulated throughout the experimental period. As an illustration, R1 strain showed the highest O.D values of 0.4 and 0.3 on day 4 and 8 respectively but R5 and R4 strains showed the highest growths of 0.564 and 0.7 O.D corresponding to day 12 and 16 while $R 2$ strain had the highest O.D value of 0.98 on day 20. The same pattern of rhizobial growths was observed at $37^{\circ} \mathrm{C}$ (Fig. 3a, b, c, d and e).

From the plate count method, R1 $(193333333.3 \mathrm{Cfu} / \mathrm{ml})$ had the highest count followed by R3 $(73333333.3 \mathrm{Cfu} / \mathrm{ml})$ at $45^{\circ} \mathrm{C}$ on day 4 (Fig. 4a). Similarly, R1 had the highest counts on day 8,12 and 16 while R3 showed the highest growth on day 20 at $45^{\circ} \mathrm{C}$ (Fig. 4b, c, d, and e). This further indicates that R1 and R3 are relatively more tolerant to heat.

\section{Rhizobial growth response under environments with different $\mathrm{pH}$}

From the spectrophotometric method, R1 strain tended to showed better growth at a $\mathrm{pH}$ of 4 at the onset of rhizobial growth response to $\mathrm{pH}$ experiment (Fig. 5a) and later decreased as the experiment progressed. However, $\mathrm{R} 1$ strain responded more positively at $\mathrm{pH} 7$ throughout the experimental sampling period (Fig. 5a, b, c and d), but R3 grew better at $\mathrm{pH} 10$ on day 5 (Fig. $5 \mathrm{a}$ ) while R5 strain was more abundant (with a cell biomass of 0.79 O.D) on day 20 under this $\mathrm{pH}$ condition (Fig. 5d).

On the other hand, from the plate count method, R1 $(120,000000 \mathrm{Cfu} / \mathrm{ml})$ had the highest count followed by $\mathrm{R} 3(100000000 \mathrm{Cfu} / \mathrm{ml})$ at $\mathrm{pH} 4$ on day 5 (Fig. 6a). On the contrary, at the same pH, R3 $(146666666.7 \mathrm{Cfu} / \mathrm{ml})$ had the highest count followed by R1 (93333333.33 Cfu/ ml) (Fig. 6a). Similarly, R3 had the highest counts on day 10 and 15 at both extreme $\mathrm{pH}$ (4 and 10) while $\mathrm{R} 4$ and $\mathrm{R} 1$ showed the highest growth on day 20 at $\mathrm{pH} 4$ and 10 respectively (Fig. 6b, c, d).

\section{Soybean seed germination}

The effects of R1, R2, R3, R4 and R5 inoculation on soybean seeds germination under drought stressed condition imposed by 4\% PEG revealed that R1 and R3 strains had a better effect on soybean germination with a percentage

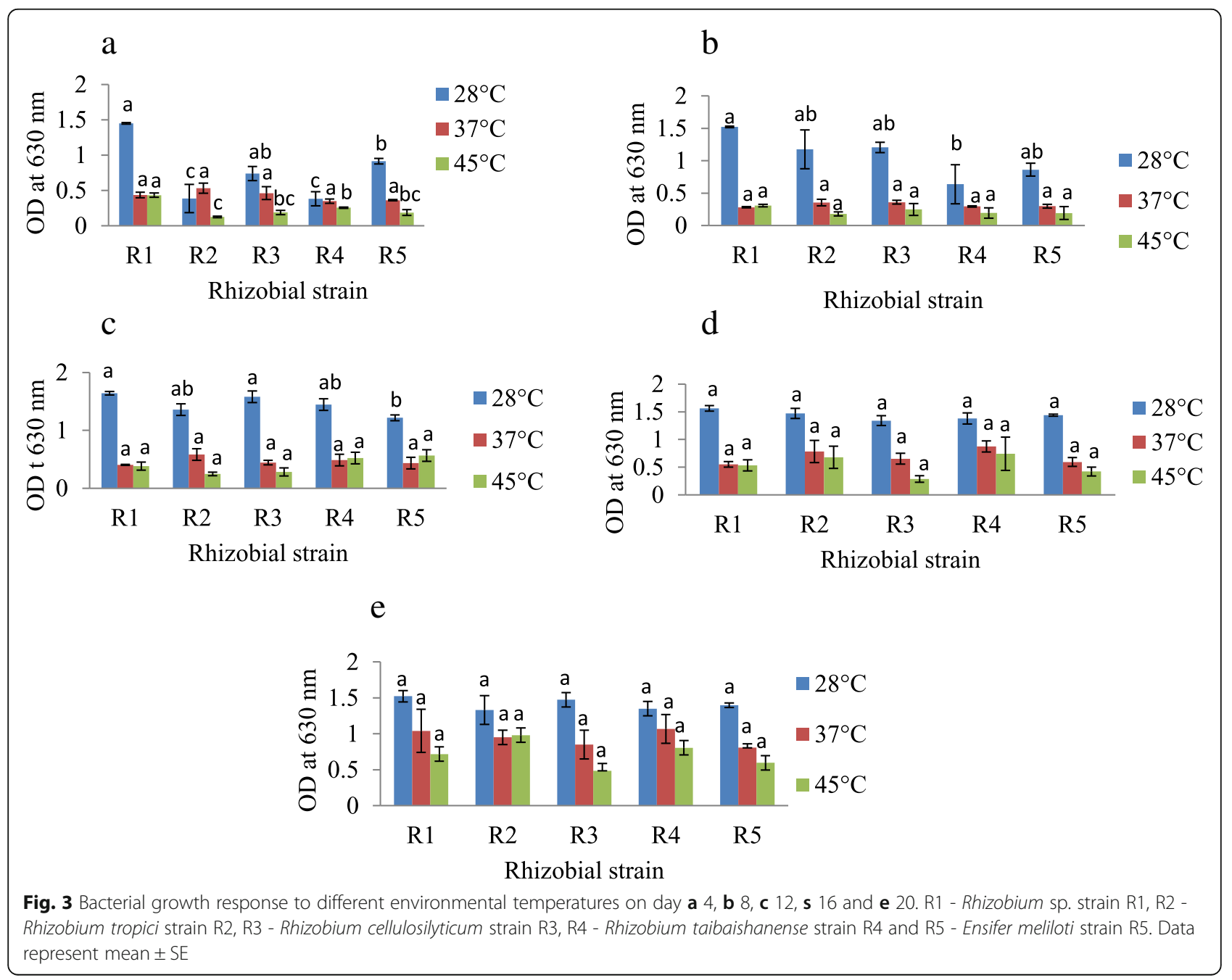


a

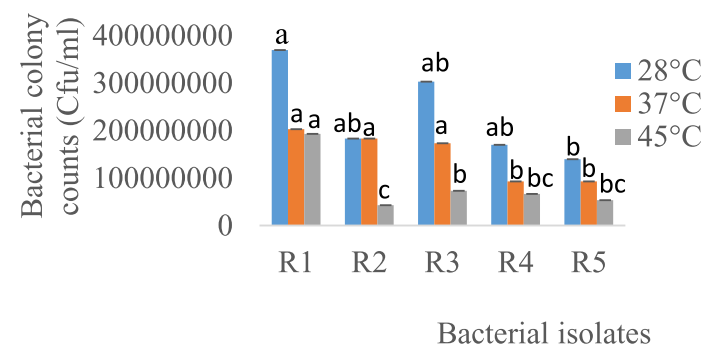

$\mathrm{C}$

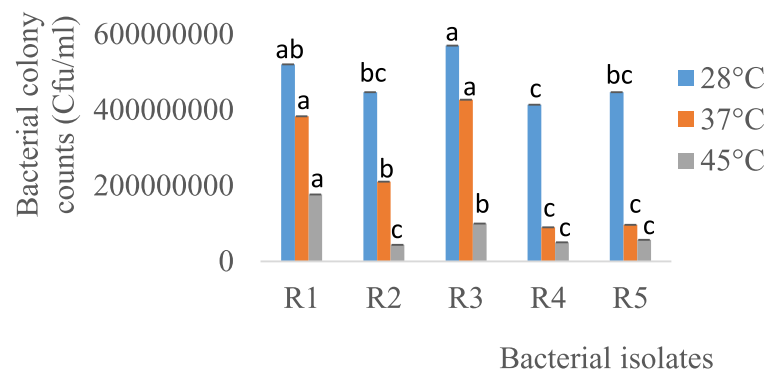

b

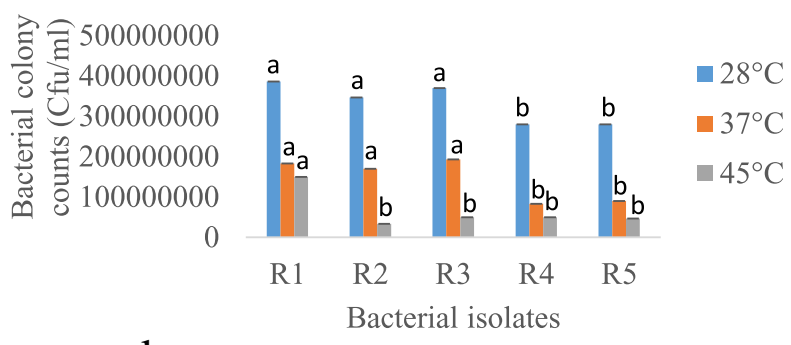

d

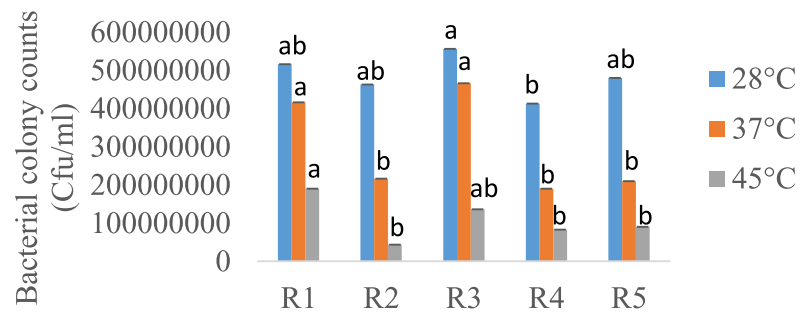

Bacterial isolates e

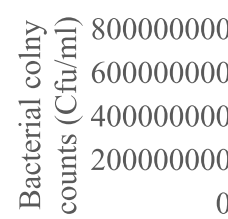

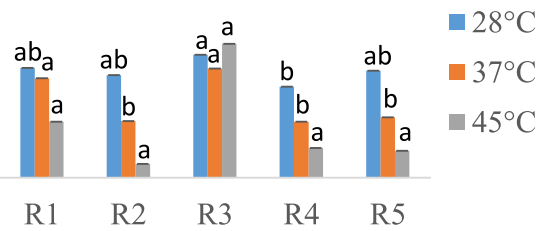

Bacterial isolates

Fig. 4 Bacterial growth response to different environmental temperatures on day a 4, b 8, c 12, d 16 and e 20. R1 - Rhizobium sp. strain R1, R2 Rhizobium tropici strain R2, R3 - Rhizobium cellulosilyticum strain R3, R4 - Rhizobium taibaishanense strain R4 and R5 - Ensifer meliloti strain R5. Data represent mean \pm SE

seed germination of $97.3 \%$ each when compared to R2, R3 and R5 strains with a percentage seed germination of 94.4, 93.3 and $93.3 \%$ respectively. However, the non-inoculated (control) experiment showed the lowest percentage seed germination of 90\% (Fig. 7). Thus, whole genome sequencing was performed for R1 and R3 strains in order to gain genomic insights into some of the functional genes that may be involved in drought tolerance, symbiotic establishment as well as plant survival and growth promotion.

\section{Genomic overview of R1 and R3 strains}

Prior to illumina sequencing, DNA concentration of $35.6 \mathrm{ng} / \mu \mathrm{L}$, DNA library concentration of $81.60 \mathrm{ng} / \mu \mathrm{L}$ with an average size of $647 \mathrm{bp}$ were generated for R1 strain while R3 strain yielded $50.2 \mathrm{ng} / \mu \mathrm{L}, 90.40$ and 661 bp corresponding to DNA concentration, final DNA library concentration and average library size (Table 2).

Upon de novo assembly, R1 strain was found to have $17,408,810$ reads with a mean length of 201.15 and a total of 5773 contigs. The number of genes predicted was 29842 with a GC content of $61.91 \%$. The $\mathrm{N}_{50}$ value of 936 was obtained for the scaffold. On the other hand, R3 strain had 17,794,094 reads with a mean read length of 214.18 and 129 contigs. The genome size of the strain was 4,114,542 with guanine-cytosine (GC) content off $43.59 \%$. The $\mathrm{N}_{50}$ value of 57294 was obtained for the scaffold.

\section{EPS producing genes}

Whole genome sequencing revealed 78 exo $X$ genes in $\mathrm{R} 1$ strain and 99 exoX genes in R3 strain and these genes are responsible for the production of exopolysaccharide in the bacterial species. Two (2) of the 78 exoX genes found in R1 strain code for signal transduction histidineprotein kinase BaeS and exodeoxyribonuclease III proteins with the corresponding baeS_1, 2.7.13.3 and xthA 3.1.11.2 aliases (Table. 3). The location of the signal transduction histidine-protein kinase gene was between 

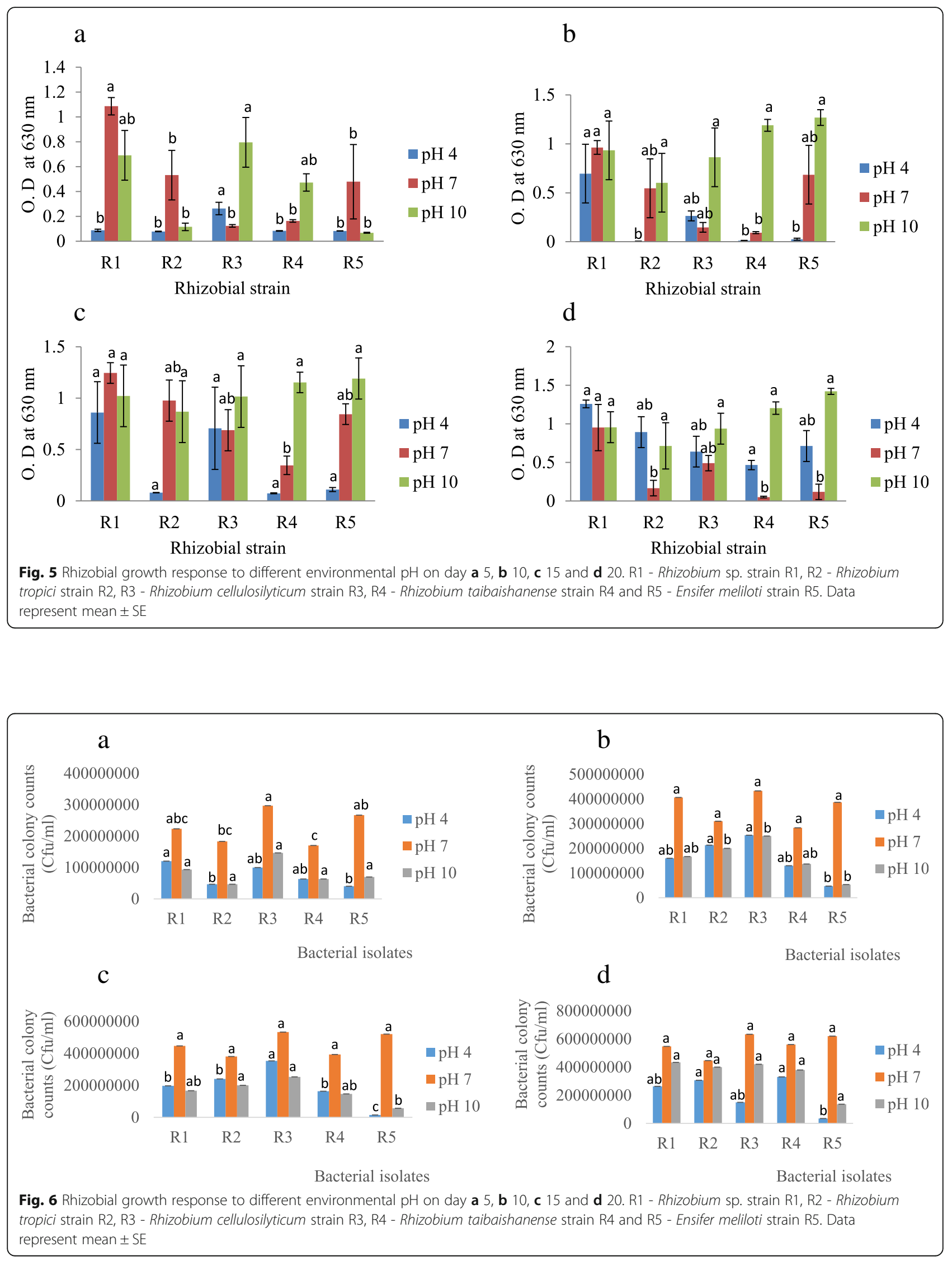


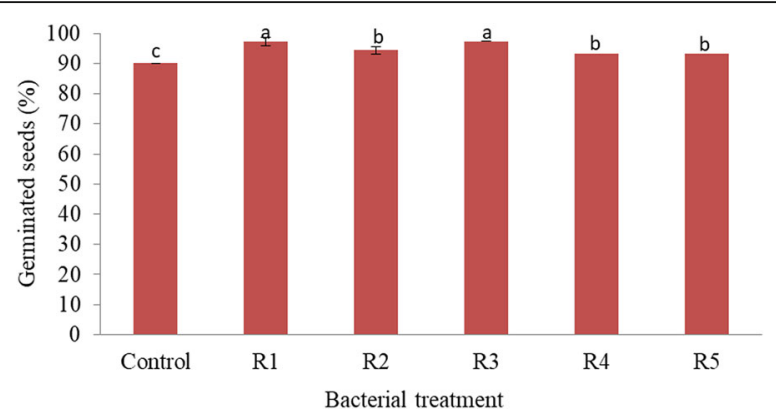

Fig. 7 Percentage of soybean seeds inoculated with rhizobial species that germinated in Petri dishes. R1 - Rhizobium sp. strain R1, R3 - Rhizobium cellulosilyticum strain R3 and R5 - Ensifer meliloti strain $\mathrm{R} 5$. Data represent mean $\pm \mathrm{SE}$

474 and 762 contigs (Fig. 8a) and that of BaeS and exodeoxyribonuclease III proteins gene was between 47 and 389 contigs (Fig. 8b). On the other hand, of the 99 exoX genes found in R3 strain, 2 encode signal transduction histidine-protein kinase ArlS and response regulator aspartate phosphatase J with arlS 2.7.13.3 and rapJ_2 3.1 aliases respectively (Table 4). Also, the location of the signal transduction histidine-protein kinase ArlS gene was between 3,808-5,173 contigs (Fig. 10a) while that of response regulator aspartate phosphatase J gene was between 26,133-27,255 contigs (Fig. 10b).

\section{High-temperature stress response genes}

Again, $5 h \operatorname{tr} A$ and $6 h \operatorname{tr} A$ genes were found in R1 and R3 strains. HtrA genes are involved in tolerance to high temperature and therefore the survival and growth of $\mathrm{R} 1$ and R3 strains observed at $45^{\circ} \mathrm{C}$ (Figs. 3a, b, c, d, e \& 4a, b, c, d, e) may be due to the high temperature tolerant proteins produced by these microorganisms (Tables 3 and 4).

Notably, 2 of the htrA genes found in R1 strain are responsible for the production of extracellular serine protease and microbial serine proteinase (Table 3) and they were located between 16 and 271 and 1,372-2,164 contigs respectively (Fig. 8c, d). In the same way, R3 strain had 2 genes coding for serine protease Do-like HtrA (Table 4) but with different contigs locations (Fig. 10c, d).

\section{Nitrogen fixing genes}

Nitrogen fixing (nif) genes are involved in the conversion of atmospheric $\mathrm{N}$ to the form that can be utilized by

Table 2 DNA final library concentration and average library size

\begin{tabular}{llll}
\hline Rhizobial species & $\begin{array}{l}\text { DNA } \\
\text { concentration } \\
(\mathrm{ng} / \mu \mathrm{L})\end{array}$ & $\begin{array}{l}\text { Final DNA } \\
\text { library concentration } \\
(\mathrm{ng} / \mu \mathrm{L})\end{array}$ & $\begin{array}{l}\text { Average library } \\
\text { size (bp) }\end{array}$ \\
\hline R1 & 35.6 & 81.60 & 647 \\
R3 & 50.2 & 90.40 & 661 \\
\hline
\end{tabular}

Legend: R1 - Rhizobium sp. strain R1 and R3 - Rhizobium cellulosilyticum strain R3 plants. Two (2) of the nif genes noticed in R1 strain are involved in the production of cysteine desulfurase SufS and cysteine desulfurase IscS with the corresponding sufS 2.8.1.7 and iscS 2.8.1.7 aliases (Table 3). The locations of these genes were between 11 and 338 contigs for cysteine desulfurase SufS gene and 1,202-1,664 (Fig. 8e) for cysteine desulfurase IscS gene (Fig. 8f). Regarding R3 strain, 2 of its nif genes are involved in the production of cysteine desulfurase IscS and Putative cysteine desulfurase NifS proteins (Table 4). These protein producing genes with different aliases also had different contigs locations (Fig. 10e, f).

\section{Nodulation genes}

Nodulation genes play a key role in nodule formation in plant roots where Rhizobium species establish symbiosis with host plants. As for R1 strain, 23297 nodA genes were found and 2 of the genes possess putative MFS-type transporter YcaD and riboflavin transporter protein potential (Table 3) with contigs locations between 93 and 735 and 734-1,091 respectively (Fig. 8g, h). On the contrary, 2 of the 12242 genes found in R3 strain code for Beta- $\mathrm{N}$ acetylglucosaminidase and Teichoic acid poly (ribitol-phosphate) polymerase situated between 4,582-7225 and 734-1,091 contigs respectively (Fig. 10g, h).

\section{Siderophore-producing genes}

At the same time, R1 strain was found to have 13 siderophore-producing genes and 2 of the genes evidently produce Catecholate siderophore Receptor Fiu and 2, 3-dihydro-2,3 dihydroxybenzoate dehydrogenase. The Catecholate siderophore Receptor Fiu gene had fiu aliases while 2, 3-dihydro-2, 3 dihydroxybenzoate dehydrogenase gene had dhbA 1.3.1.28 aliases (Table 3) situated between contigs 662-1,424 (Fig. 9a) and 59-572 (Fig. 9b) within the genome. With respect to R3 strain, it had 33 siderophore-producing genes and 2 of the genes and their respective contigs locations within the genome are shown in Table 4 and Fig. 11a, b accordingly.

\section{IAA producing genes}

Unlike R3 strain, 1 CDS and 1 IAA producing-gene were found in R1 strain with the biological function of Isoaspartyl peptidase (Table 3) and they were both located within 536-704 contigs (Fig. 9c, d). But, R3 strain had 6 IAA-producing genes and 2 of the genes produce inner membrane protein YiaA and tRNA dimethylallyltransferase proteins with the corresponding yiaA and miaA 2.5.1.75 aliases. The locations of their respective gene were also different within the genome (Fig. 11c, d). In reality, proteins produced by these genes can be involved in root elongation and lateral root production in plants. 
Table 3 Selected stress tolerance, symbiotic and plant growth promoting functional genes found in the genome of Rhizobium sp. strain R1

\begin{tabular}{|c|c|c|c|c|c|c|}
\hline Feature ID & Type & Function & Aliases & Start & Length & Location \\
\hline \multicolumn{7}{|l|}{$\overline{E x O X}$} \\
\hline JKFNCFJO_00944 & gene & $\begin{array}{l}\text { Signal transduction histidine-protein } \\
\text { kinase BaeS }\end{array}$ & $\begin{array}{l}\text { baes_1, } \\
\text { 2.7.13.3 }\end{array}$ & 762 & 288 & $\begin{array}{l}\text { Contig: NODE_1409_length_750_ } \\
\text { cov_2.449333 } \\
\text { 474-762 (- Strand) }\end{array}$ \\
\hline JKFNCFJO_01811 & gene & Exodeoxyribonuclease III & $x$ thA, 3.1.11.2 & 47 & 342 & $\begin{array}{l}\text { Contig:NODE_2692_length_718_ } \\
\text { cov_3.898329 } \\
\text { 47-389 (+ Strand) }\end{array}$ \\
\hline \multicolumn{7}{|l|}{$\mathrm{HtrA}$} \\
\hline JKFNCFJO_06099 & gene & Extracellular serine protease & 3.4.21.- & 16 & 255 & $\begin{array}{l}\text { Contig: NODE_11432_length_1141_ } \\
\text { cov_2.421560 } \\
16-271 \text { (+Strand) }\end{array}$ \\
\hline JKFNCFJO_02038 & gene & Microbial serine proteinase & aspA, 3.4.21.- & 2164 & 792 & $\begin{array}{l}\text { Contig:NODE_3069_length_2224_cov_ } \\
\text { 3.164568 } \\
\text { 1,372-2,164 (-strand) }\end{array}$ \\
\hline \multicolumn{7}{|l|}{ Nif genes } \\
\hline JKFNCFJO_00231 & gene & Cysteine desulfurase SufS & sufS, 2.8.1.7 & 11 & 327 & $\begin{array}{l}\text { Contig: NODE_344_length_1119_ } \\
\text { cov_2.287757 } \\
11-338 \text { (+Strand) }\end{array}$ \\
\hline JKFNCFJO_04114 & gene & Cysteine desulfurase IscS & iscs, 2.8.1.7 & 1,664 & 462 & $\begin{array}{l}\text { Contig: NODE_6900_length_1667_ } \\
\text { cov_2.808638 } \\
\text { 1,202-1,664 (-Strand) }\end{array}$ \\
\hline \multicolumn{7}{|l|}{ Nod A } \\
\hline JKFNCFJO_00001 & gene & $\begin{array}{l}\text { putative MFS-type transporter } \\
\text { YcaD }\end{array}$ & ycaD_1 & 93 & 642 & $\begin{array}{l}\text { Contig: NODE_1_length_1071_cov_ } \\
2.464052 \\
93-735 \text { (+Strand) }\end{array}$ \\
\hline JKFNCFJO_00002 & gene & Riboflavin transporter & ribN & 1,091 & 357 & $\begin{array}{l}\text { Contig: NODE_1_length_1071_cov_ } \\
2.464052 \\
734-1,091 \text { (- Strand) }\end{array}$ \\
\hline \multicolumn{7}{|l|}{ Siderophore } \\
\hline JKFNCFJO_00628 & gene & $\begin{array}{l}\text { Catecholate siderophore } \\
\text { Receptor Fiu }\end{array}$ & fiu & 1,424 & 762 & $\begin{array}{l}\text { Contig: NODE_980_length_1476_cov_ } \\
2.882791 \\
662-1,424 \text { (- Strand) }\end{array}$ \\
\hline JKFNCFJO_07774 & gene & $\begin{array}{l}\text { 2,3-dihydro-2,3-dihydroxybenzoate } \\
\text { dehydrogenase }\end{array}$ & $\begin{array}{l}\text { dhbA, } \\
\text { 1.3.1.28 }\end{array}$ & 59 & 513 & $\begin{array}{l}\text { Contig: NODE_18194_length_629_cov_ } \\
2.839428 \\
59-572 \text { (+ Strand) }\end{array}$ \\
\hline \multicolumn{7}{|l|}{ IAA } \\
\hline $\begin{array}{l}\text { JKFNCFJO_03956_ } \\
\text { CDS }\end{array}$ & CDS & Isoaspartyl peptidase & iaaA, 3.4.19.5 & 704 & 168 & $\begin{array}{l}\text { Contig: NODE_6586_length_704_cov_ } \\
2.566761 \\
536-704 \text { (- Strand }\end{array}$ \\
\hline JKFNCFJO_03956 & gene & Isoaspartyl peptidase & iaaA, 3.4.19.5 & 704 & 168 & $\begin{array}{l}\text { Contig: NODE_6586_length_704_cov_ } \\
2.566761 \\
536-704 \text { (-Strand) }\end{array}$ \\
\hline \multicolumn{7}{|l|}{ EptA gene } \\
\hline JKFNCFJO_06547 & gene & $\begin{array}{l}\text { UDP-N-acetylmuramate--L-alanyl-gamma- } \\
\text { D-glutamyl-meso-2,6-diaminoheptandioate } \\
\text { ligase }\end{array}$ & $\mathrm{mpl}$, 6.3.2.45 & 782 & 1,365 & $\begin{array}{l}\text { Contig: NODE_12707_length_2871_cov__ } \\
2.986416 \\
782-2,147 \text { (+ Strand) }\end{array}$ \\
\hline JKFNCFJO_05747 & gene & Phosphoethanolamine transferase EptA & $\begin{array}{l}\text { eptA_3, 2.7.- } \\
\text {-- }\end{array}$ & 42 & 534 & $\begin{array}{l}\text { Contig: NODE_10489_length_1026_ } \\
\text { cov_2.685185 } \\
42-576 \text { (+Strand) }\end{array}$ \\
\hline
\end{tabular}

\section{Low-pH stress response genes}

As a matter of fact, R1 and R3 strains were also found to possess genes that are involved in tolerance to low $\mathrm{pH}$ environments and one of them reported in this study is collectively called eptA. Indeed, R1 strain had 12 eptA genes and 2 of the genes were found to have the biological functions shown in Table 3. R3 strain also had several of the eptA genes and 2 of the 


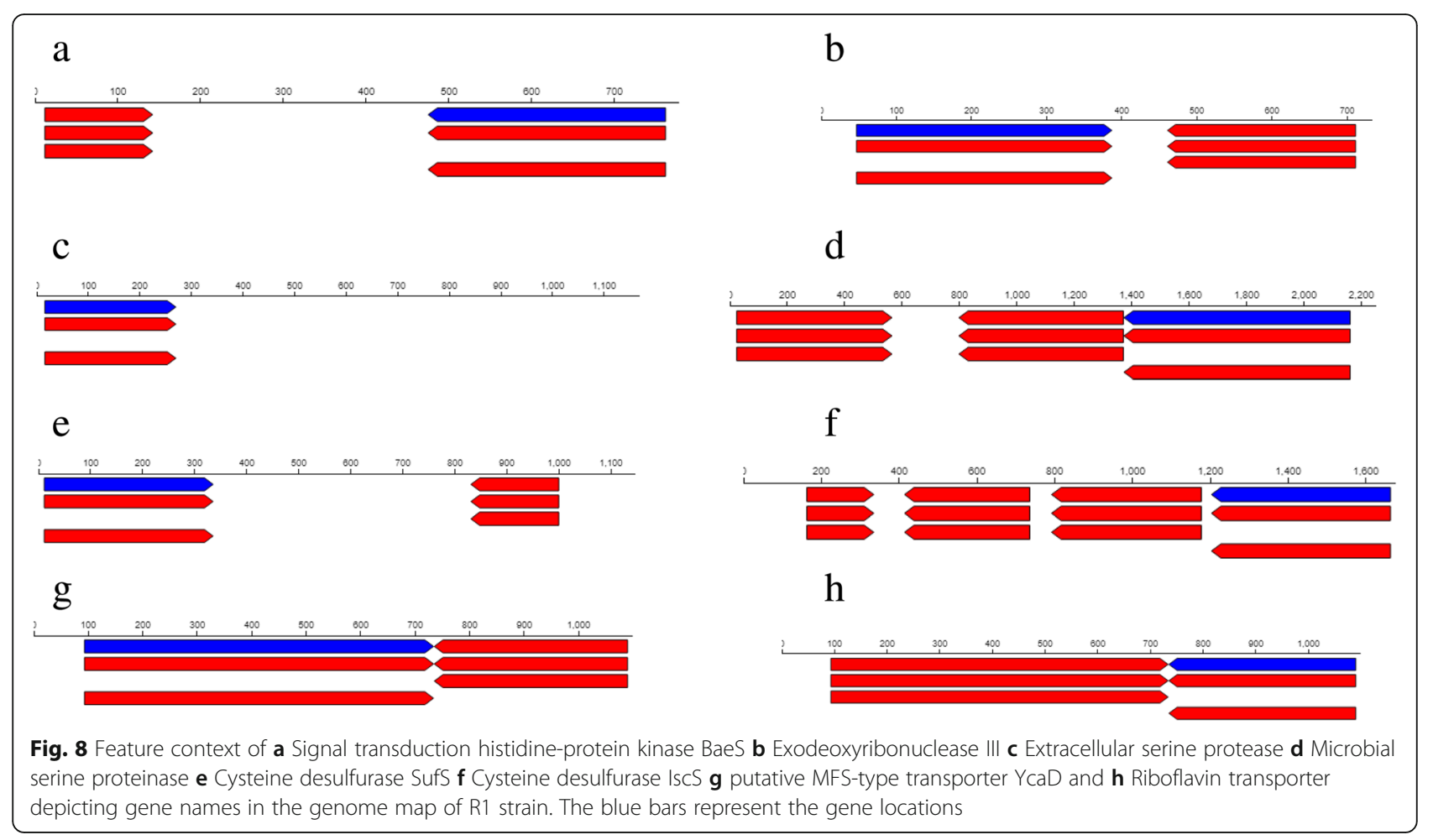

genes had heptaprenyl diphosphate synthase component 1 and septation ring formation regulator EzrA biological functions (Table 4). These genes were found to be located within different contigs locations in the genome of R1 (Fig. 9e, f) and R3 (Fig. 11e, f) strains.

\section{Discussion}

In this present study, the plant growth promoting traits of rhizobial species were determined. To be specific, the ACC experiment revealed the production of ACC by the rhizobial species (Fig. 2a) but the highest concentration of ACC was produced by R5 strain followed by R1 strain while the lowest concentration of ACC was produced by R2 strain. The production of ACC by these microorganisms shows that they have the potential to increase plant tolerance to drought stress since it was reported by [25] that application of 'ACC deaminase-producing microorganisms' into water stressed soil environments can reduce stress in the local plants by minimizing stress triggered by $\mathrm{C}_{2} \mathrm{H}_{4}$. Indeed, a study carried out by [35] showed that ACC deaminase-producing Pseudomonas species partially eradicated the detrimental effects of water stress on pea (Pisum sativum L.) growth and/or productivity.

In a study performed by [27], bacterial tolerance to water stress conditions was characterized by EPS production and therefore in this study, rhizobial tolerance to drought stress was determined by their ability to produce EPS in medium amended with different concentrations of
PEG (drought stress stimulant). Based on the qualitative results, we found that environmental stresses such as $\mathrm{pH}$ and temperature stimulated the production of EPS. In particular, R2, R3 and R4 strains produced EPS under the different $\mathrm{pH}$ and temperature conditions (Table 1). Quantitatively, our findings showed that R1 strain was more effective in EPS production under severe drought condition (10\% PEG) while R2 strain produced more EPS at 5\% PEG (Fig. 2b). Other rhizobial species produced EPS at different concentrations in this study. Indeed, EPS production by bacteria protect them from water stress, heavy metals and other environmental stresses [27, 36], and therefore, it is possible for these rhizobial species to survive, multiply and harness other plant growth promoting traits when applied under drought conditions - as evident in the soybean germination experiment (Fig. 7) even in a complex soil environment in the field.

Indeed, siderophore production by different microorganisms has been reported by many researchers [37, 38]. In this present study, the 'maximum siderophore production' was found in King B broth. These quantitative results for siderophore production further validate the qualitative plate test for siderophore production for these rhizobial species in our previous study (data not shown). However, the results of this study contradict the findings of [28] who reported maximum siderophore production by Pseudomonas species in succinic acid broth.

The rhizobial species used in this study showed other plant growth promoting traits. In particular, all the 
Table 4 Selected stress tolerance, symbiotic and plant growth promoting functional genes found in the genome of $R$. cellulosilyticum strain R3

\begin{tabular}{|c|c|c|c|c|c|c|}
\hline Feature ID & Type & Function & Aliases & Start & length & Location \\
\hline \multicolumn{7}{|l|}{ Exo $X$ gene } \\
\hline LKIIOFBO_00637 & gene & $\begin{array}{l}\text { Signal transduction histidine- } \\
\text { protein kinase ArlS }\end{array}$ & arls, 2.7.13.3 & 5,173 & 1,365 & $\begin{array}{l}\text { NODE_12_length_14500_cov_ } \\
30.995518 \\
\text { 3,808-5,173 (-Strand) }\end{array}$ \\
\hline LKIIOFBO_01604 & gene & $\begin{array}{l}\text { Response regulator aspartate } \\
\text { phosphatase J }\end{array}$ & rapJ_2, 3.1..-- & $\begin{array}{l}26 \\
133\end{array}$ & 1,122 & $\begin{array}{l}\text { NODE_32_length_40656_cov_ } \\
\text { 31.105864 } \\
\text { 26,133-27,255 (+Strand) }\end{array}$ \\
\hline \multicolumn{7}{|l|}{ htrA } \\
\hline LKJIOFBO_03117 & gene & Serine protease Do-like HtrA & htrA_1, 3.4.21.107 & 6,151 & 1,203 & $\begin{array}{l}\text { Contig:NODE_64_length_16935_ } \\
\text { cov_30.627930 } \\
6,151-7,354 \text { (+ Strand }\end{array}$ \\
\hline LKIOFBO_04119 & gene & Serine protease Do-like HtrA & htrA_2, 3.4.21.107 & $\begin{array}{l}24 \\
021\end{array}$ & 1,362 & $\begin{array}{l}\text { Contig:NODE_203_length_47982_ } \\
\text { cov_29.809929 } \\
\text { 24,021-25,383 (+ Strand) }\end{array}$ \\
\hline \multicolumn{7}{|l|}{ Nif gene } \\
\hline LKIOFBO_00593 & Gene & Cysteine desulfurase IscS & iscS_2, 2.8.1.7 & $\begin{array}{l}40 \\
060\end{array}$ & 1,146 & $\begin{array}{l}\text { NODE_11_length_78586_cov_ } \\
30.601507\end{array}$ \\
\hline $\begin{array}{l}\text { LKJIOFBO_01424_ } \\
\text { CDS }\end{array}$ & CDS & Putative cysteine desulfurase NifS & nifS, 2.8.1.7 & 72 & 264 & $\begin{array}{l}\text { NODE_29_length_80092_cov_ } \\
31.155697\end{array}$ \\
\hline \multicolumn{7}{|l|}{ Nod A } \\
\hline LKIOFBO_00005 & gene & Beta-N acetylglucosaminidase & lytD, 3.2.1.96 & 4,582 & 2,643 & $\begin{array}{l}\text { Contig: NODE_1_length_64013_ } \\
\text { cov_32.129894 } \\
\text { 4,582-7225 (+Strand) }\end{array}$ \\
\hline LKIOFBO_00006 & gene & $\begin{array}{l}\text { Teichoic acid poly } \\
\text { (ribitol-phosphate) polymerase }\end{array}$ & $\operatorname{tarL}, 2.7 .8 .-$ & & & $\begin{array}{l}\text { Contig: NODE_1_length_64013_ } \\
\text { cov_32.129894 } \\
\text { 7,268-9,128 (- Strand) }\end{array}$ \\
\hline \multicolumn{7}{|l|}{ Siderophore } \\
\hline LKIOFBO_02039 & gene & $\begin{array}{l}\text { putative siderophore transport } \\
\text { system permease protein YfiZ }\end{array}$ & yfiz_1 & $\begin{array}{l}14 \\
769\end{array}$ & 1,002 & $\begin{array}{l}\text { Contig: NODE_38_length_39997_ } \\
\text { cov_29.245344 } \\
\text { 14,769-15,771 (+ Strand) }\end{array}$ \\
\hline LKIOFBO_02038 & gene & $\begin{array}{l}\text { putative siderophore-binding } \\
\text { lipoprotein YfiY }\end{array}$ & yfiY & $\begin{array}{l}14 \\
769\end{array}$ & 978 & $\begin{array}{l}\text { Contig: NODE_38_length_39997_ } \\
\text { cov_29.245344 } \\
\text { 13,660-14,638 (- Strand) }\end{array}$ \\
\hline \multicolumn{7}{|l|}{ IAA } \\
\hline LKIOFBO_01515 & gene & Inner membrane protein YiaA & yiaA & $\begin{array}{l}11 \\
965\end{array}$ & 264 & $\begin{array}{l}\text { Contig: NODE_30_length_44008_ } \\
\text { cov_32.195396 } \\
11,701-11,965 \text { (- Strand) }\end{array}$ \\
\hline LKJIOFBO_02665 & gene & tRNA dimethylallyltransferase & miaA, 2.5.1.75 & $\begin{array}{l}10 \\
955\end{array}$ & 945 & $\begin{array}{l}\text { Contig: NODE_48_length_27057_ } \\
\text { cov_29.404369 }\end{array}$ \\
\hline \multicolumn{7}{|l|}{ EptA } \\
\hline LKIOFBO_03929 & gene & $\begin{array}{l}\text { Heptaprenyl diphosphate synthase } \\
\text { component } 1\end{array}$ & hepS, 2.5.1.30 & 8,080 & 765 & $\begin{array}{l}\text { Contig: NODE_102_length_18176_ } \\
\text { cov_29.706535 } \\
\text { 7,315-8,080 (- Strand) }\end{array}$ \\
\hline LKIOFBO_00595 & gene & $\begin{array}{l}\text { Septation ring formation } \\
\text { regulator EzrA }\end{array}$ & ezrA & $\begin{array}{l}43 \\
376\end{array}$ & 1,689 & $\begin{array}{l}\text { Contig: NODE_11_length_78586_ } \\
\text { cov_30.601507 } \\
41,687-43,376 \text { (- Strand) }\end{array}$ \\
\hline
\end{tabular}

rhizobial species produced IAA but at different concentrations. This is in agreement with the report that IAA production can differ among different bacterial species, which can be influenced by culture condition, nutrient availability and growth stage [19]. In addition, bacteria from plant rhizosphere are more effective producers of
IAA than those from bulk soil [39]. In this study, we observed that R3 strain was more efficient in producing IAA at both concentrations of tryptophan (Fig. 2d) and this could be the reason for the high root biomass observed in soybean treated with this species in our previous study (data not shown), since IAA production has 


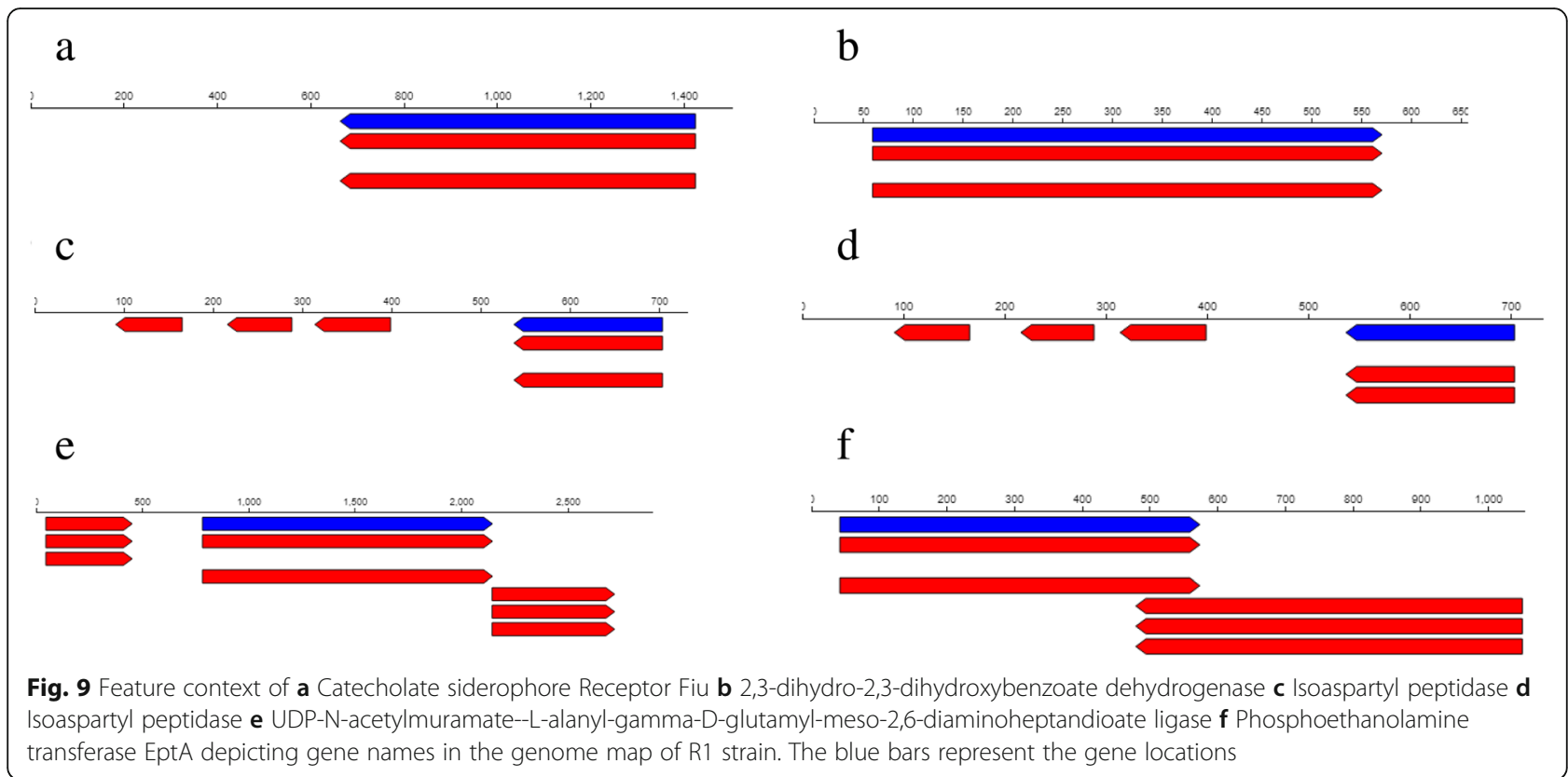

been implicated in root elongation and development of lateral roots [19].

Another strategic mechanism that can be used by rhizospheric bacteria to support the growth of agricultural crops lies in their capacity to solubilize phosphate, and it has been stated that phosphates always occur in bound forms in the soil [27]. Indeed, we found that R2 strain was more effective in solubilizing tri-calcium phosphate in Pikovskaya's agar followed by R1 strain, but R3 and R4 strains showed similar phosphate solubilizing potential while R5 strain demonstrated the least ability to degrade phosphate as shown in Fig. 2e. Thus, these rhizobial species have the tendency to solubilize bound phosphates and make them available for plant uptake in the soil.

Additionally, rhizobial growth response towards different environmental temperatures showed that these species possess the capacity to thrive and survive at relatively high temperature $\left(45^{\circ} \mathrm{C}\right)$. It has been shown that the optimal growth temperature for many rhizobial species is $25-30^{\circ} \mathrm{C}$ [40], which agrees with our findings, since in this study, rhizobial species grew best at $28^{\circ} \mathrm{C}$. The ability of these species to grow and survive at 37 and $45^{\circ} \mathrm{C}$ indicate that they may be able to help agricultural crops such as soybean to survive in most tropical countries currently facing drought and/or high temperature problems and further contradict the report of $[41,42]$ that soybean rhizobial species grow poorly at $40^{\circ} \mathrm{C}$ and none of the species is 'able to grow' at $42^{\circ} \mathrm{C}$. On the contrary, some rhizobial species capable of nodulating common bean (Phaseolus vulgaris) can survive at $47^{\circ} \mathrm{C}$, although they do not have the ability to form nodules at such high temperatures [43]. Other rhizobial species from Phaseolus vulgaris are able to survive and remain infective at $40^{\circ} \mathrm{C}[41]$.

Additionally, the ability of rhizobial species to grow and survive at different $\mathrm{pH}$ was experimented in this study, since real-life biotechnological application of microbial inoculants under drought condition in the field would demand that these species should possess the capacity to adapt to $\mathrm{pH}$ fluctuations inherent in complex soil ecosystem. Thus, all the rhizobial species in this current study were able to grow and survive in acidic ( $\mathrm{pH} 4)$, neutral ( $\mathrm{pH} 7)$ and alkaline environments (pH 10) (Fig. 5a, b, c, d \& 6 a, b, c, d), indicating that these species possibly have broad environmental adaptability with respect to environmental $\mathrm{pH}$. Such trait can help these microorganisms to function actively (without interference) in their symbiotic interactions with crops, since it was reported by [44] that nodulation of faba bean treated with Rhizobium leguminosarum was inhibited significantly by soil alkalinity.

The use of R1, R2, R3, R4 and R5 strains for in vitro enhancement of soybean germination under drought condition stimulated by 4\% PEG showed that R1 and R3 strains were able to effectively enhance the germination of soybean than R2, R4 and R5 strains. This result showed that R1 and R3 strains were able to enhance the germination of soybean more effectively than the other 3 strains. This finding is in agreement with the results of [45] who reported that 'ACC deaminase - producing fluorescent pseudomonads' improved canola (Brassica napus L) seed germination under osmotic stress.

Regarding genomic insights into R1 and R3 strains, annotation of R3 genome revealed the presence of 99 different genes (exo genes) responsible for EPS production. One of the genes with aliases $y j c G$ had the biological function of putative phosphoesterase while ArlS gene had the biological 
function of signal transduction histidine-protein kinase. These EPS genes are known to empower microorganisms to survive under harsh environmental conditions [11]. Although, it has been reported that EPS production is a survival strategy needed by microorganisms under drought stress condition, [1] reported that production of EPS is connected to acid tolerance. In reality, EPS has also been produced by Agrobacterium tumefaciens and S. meliloti in acidic environments [46-48].

Under certain circumstances, surface polysaccharides such as EPS, capsular polysaccharides (CPS), $\beta$ - 1,2 -glucans and lipopolysaccharides (LPS), which are essential molecules for symbioses establishment $[49,50]$ might have other functions such as defense against antimicrobial substances and oxidative stress [51-53]. Different types of exo genes have been reported [54], but in this study, we are reporting only exo $X$ genes produced by $\mathrm{R} 1$ and $\mathrm{R} 3$ strains. It was also reported by [54] that exo $X$ gene regulates the production of exopolysaccharide (such as succinoglycan) by a 'new Rhizobium meliloti'. The 2 exoX genes reported for R1 strain were located between contigs 474-762 and 47-389 (Fig. 8a, b) with signal transduction histidine-protein kinase $\mathrm{BaeS}$ and exodeoxyribonuclease III biological functions respectively (Table 3). Similarly, R3 strain had its 2 exoX genes located between 3,808-5,173 and 26,133-27,255 (Fig. 10a, b) with signal transduction histidine-protein kinase ArlS and response regulator aspartate phosphatase J functions respectively (Table 4).

As previously mentioned, R1 and R3 strains were able to survive and grow at $45^{\circ} \mathrm{C}$ (Fig. 3a, b, c, d, e \& 4 a, b, c, d, e) and this trait is thought to be essential for their success as semiarid and/or arid inoculant species [1, 55, 56]. A number of proteins are induced upon exposure to relatively high temperatures and these proteins are generally termed heat shock proteins (HSPs). A couple of HSPs were present in R1 strain and $h t r A$ genes were found in both R1 and R3 strains. Specifically, $5 \mathrm{htrA}$ and $14 h \operatorname{tr} A$ genes were correspondingly found in R1 and R3 strains. Besides, many different htrA homologues are similarly found in the genome of other bacteria [57]. However, it was reported that alterations in one ' $h t r A$ paralogue' of Brucella abortus and S. meliloti had only a little impact on growth at high temperatures [58, 59], perhaps as a result of functional redundancy. Furthermore, [1] also reported htrA gene as one of the components of heat shock response in Rhizobium tropici CIAT 899 and Rhizobium sp. PRF 81. In reality, besides high temperatures, some HSPs also offer protection against other stressful conditions such as the DnaK machinery which protects against salt stress [60] and even the HtrA that proffers fortification against oxidative damage [59]. Among the htrA found in the rhizobial strains in this

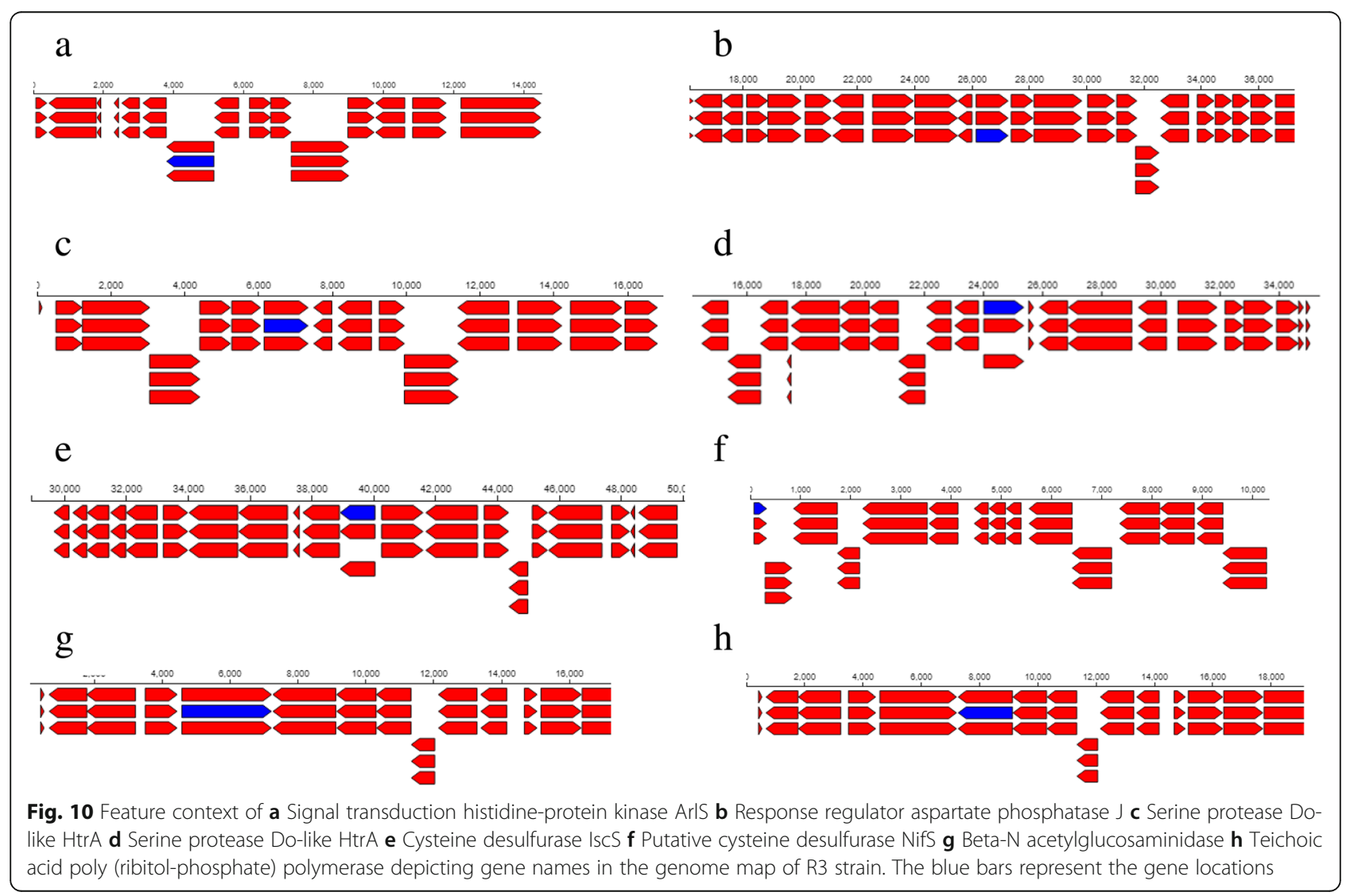




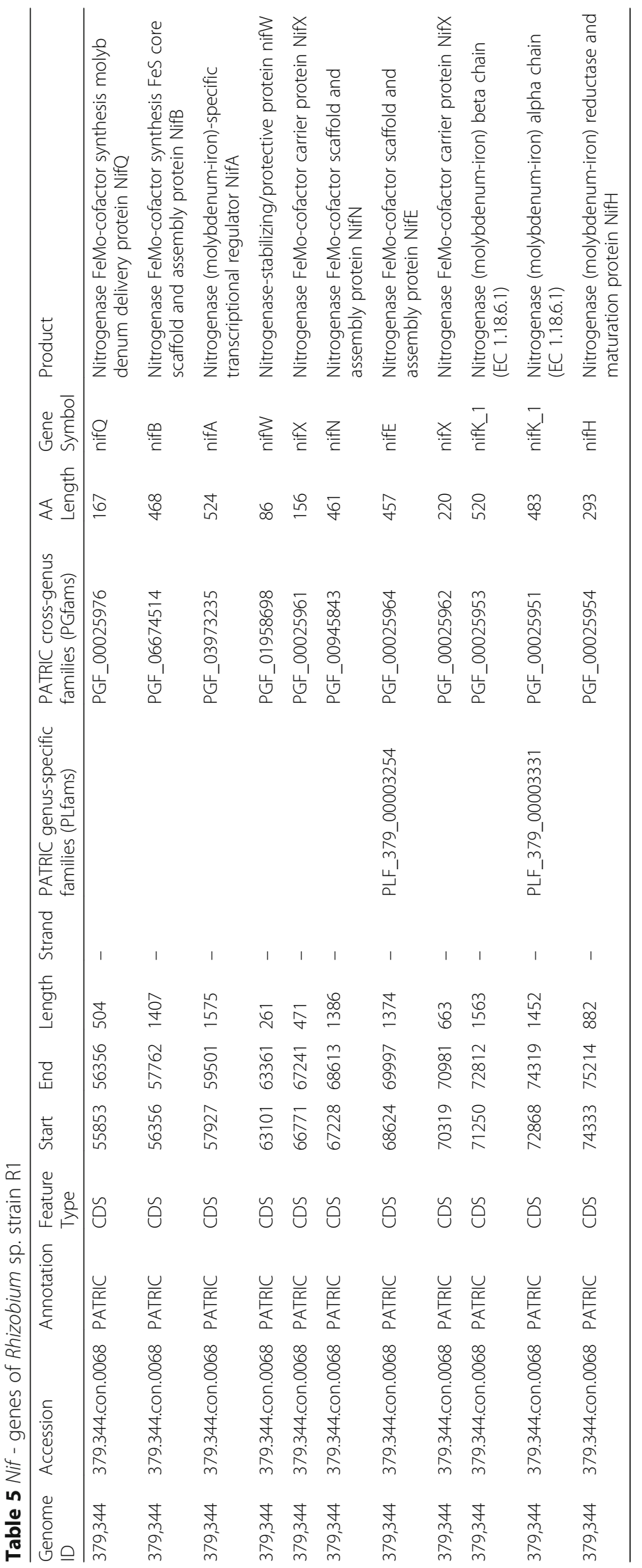




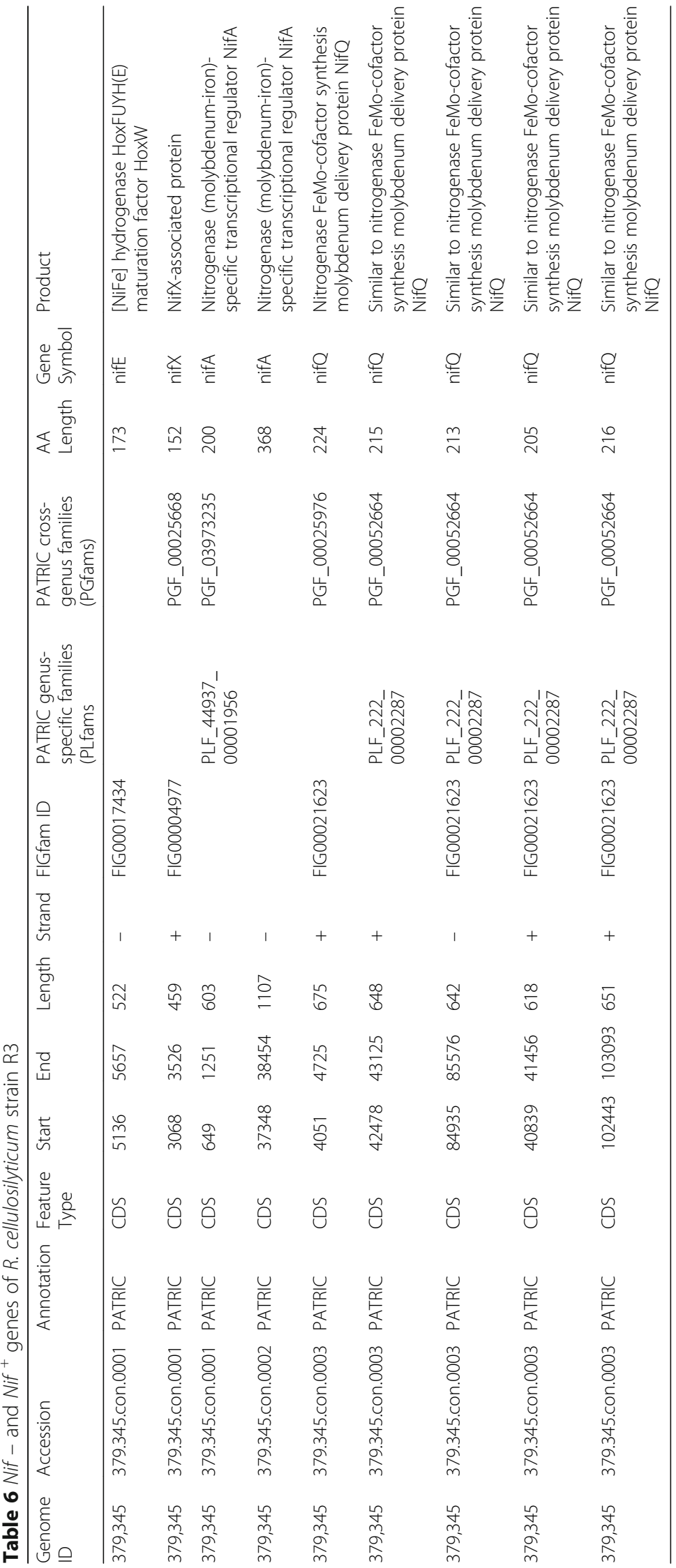


present study are the R1 strain extracellular serine protease and microbial serine proteinase $h t r A$ (Table 3 ) and the R3 strain serine protease Do-like $h t r A$ and serine protease Do-like htrA (Table 4). Again, both htrA genes for R1 strain (Fig. 8c, d) and R3 strain (Fig. 10c, d) have their unique contigs locations within the genome.

R1 and R3 strains harbored nitrogen fixing (nif) genes with 6 different biological functions and 2 of the genes are presented in Tables 3 and 4 respectively. With respect to location, iscS_1, 2.8.1.7 gene was located between contigs 38, 300-39,443 (Fig. 10e) while nifS was located between contigs 72-336 (Fig. 10f) in R3 strain but the nif genes in $\mathrm{R} 1$ were found at contigs locations (Fig. 8e, f) different from that of R3 strain. IscS has the biological function of providing sulphur for the synthesis of iron-sulphur cluster in vitro; nevertheless, in vivo role of IscS in iron-sulphur formation is yet to be established [61]. Studies of the Azotobacter vinelandii nitrogen fixation gene cluster revealed that there are activities that enhance the effectiveness of iron-sulphur cluster assembly [62]. To be specific, study of nifS led to the detection that the protein produced by IscS gene is a pyridoxal 59-phosphate-haboring cysteine desulfurase that helps to transfer the sulfur moiety from cysteine to cysteinyl active site of nifS leading to the formation of enzyme-bound persulfide [63]. After reduction and incorporation of an iron source, the sulphur can be released and effectively integrated into the iron-sulphur protein cluster of the nitrogenase enzyme complex [63].

However, R1 strain was found to possess other types of nif genes such as nifW, nifN, nifQ etc. with negative $(-)$ strands and these genes were found to have different biological products (Table 5). Also, R3 strain was also found to possess different nitrogen fixing genes with almost similar products, for instance, nif $X$ and nifQ both with positive $(+)$ strands with biological products similar to nitrogenase FeMo-cofactor synthesis molybdenum delivery protein NifQ (Table 6).

Also, we found 23297 and 12242 nodA genes in R1 and R3 strains respectively but only 2 of the genes are reported for each strain in this study. Particularly, we observed NodA genes encoding putative MFS-type transporter YcaD and riboflavin transporter in R1 strain (Table 3) and Beta- $\mathrm{N}$ acetylglucosaminidase and Teichoic acid poly (ribitol-phosphate) polymerase in R3 strain (Table 4). The location of putative MFS-type transporter YcaD was between contigs 93-735 (Fig. 8g), riboflavin transporter was between contigs 734-1091 (Fig. 8h), Beta-N acetylglucosaminidase was between contigs 4582-7225 (Fig. 10g) and Teichoic acid poly (ribitol-phosphate) polymerase was between contigs 7268-9128 (Fig. 10h). It is a common knowledge that Nod genes help in the formation of nodules, the site of nitrogen fixation by nitrogen fixing bacteria such as Rhizobium species. Moreover, it was suggested that the kind of 'Nod factor acyl group attached by NodA can contribute to the determination of host range' [1, 64]. NodA gene was also reported by [1] as one of the nodulation genes found in Rhizobium species.

In addition, R1 strain was noticed to have gene with + strand responsible for the production of nodulation protein $\mathrm{N}$ (Table 7) while R3 possesses genes, one with + strand and another with - strand, that can produce protein translocase subunit $\mathrm{SecD} /$ protein translocase subunit SecF and swarming motility protein SwrC (Table 8).

R1 and R3 strains were found to have 13 and 33 siderophore-producing genes respectively. To be specific, Catecholate siderophore receptor fiu and 2, 3dihydro-2, 3-dihroxybenzoate dehydrogenase genes were noticed in R1 strain (Table 3) while putative siderophore transport system permease protein YfiZ and putative siderophore-binding lipoprotein YfiY genes were detected in R3 strain (Table 4). It is presumed that these siderophore protein-producing genes in R1 strain located between contigs $662-1,424$ and 59-572 (Fig. 9a, b) and in R3 strain located between 14769 and 15,771 and 13,660-14,638 (Fig. 11a, b) could have contributed to the quantitative siderophore production (Fig. 2c) observed in this study, which can help these rhizobia strains to chelate Fe and make it available for plant use. Naturally, the role of siderophore producing-rhizobia under drought conditions is highly appreciated since it was reported by [65] that plants are highly prone to pathogenic attack under water stress conditions. Siderophore is obviously antimicrobial in nature [2] and thus application of siderophore-producing rhizobia will certainly help to improve plant health under drought stress and consequently increase agricultural productivity [66].

Furthermore, IAA genes involved in the production of Isoaspartyl peptidase protein was detected in R1 strain (Table 3). Similarly, 2 of the 6 IAA genes found in R3 strain are responsible for the production of inner membrane protein YiaA and tRNA dimethylallyltransferase

Table 7 Nod + gene of Rhizobium sp. strain R1

\begin{tabular}{|c|c|c|c|c|c|c|c|c|c|c|c|c|}
\hline $\begin{array}{l}\text { Genome } \\
\text { ID }\end{array}$ & Accession & Annotation & $\begin{array}{l}\text { Feature } \\
\text { Type }\end{array}$ & Start & End & Length & Strand & $\begin{array}{l}\text { PATRIC } \\
\text { genus-specific } \\
\text { families } \\
\text { (PLfams) }\end{array}$ & $\begin{array}{l}\text { PATRIC cross- } \\
\text { genus families } \\
\text { (PGfams) }\end{array}$ & $\begin{array}{l}\text { AA } \\
\text { Length }\end{array}$ & $\begin{array}{l}\text { Gene } \\
\text { Symbol }\end{array}$ & Product \\
\hline 379,344 & 379.344.con.0013 & PATRIC & CDS & 117351 & 117827 & 477 & + & & $\begin{array}{l}P_{\text {PGF_- }} \\
12857966\end{array}$ & 158 & & $\begin{array}{l}\text { Nodulation } \\
\text { protein } N\end{array}$ \\
\hline
\end{tabular}




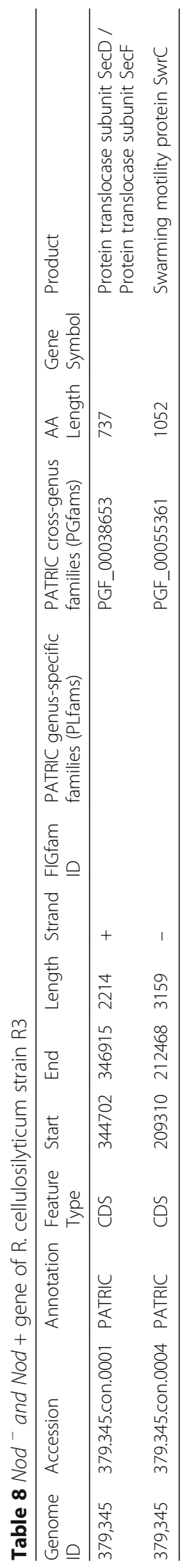




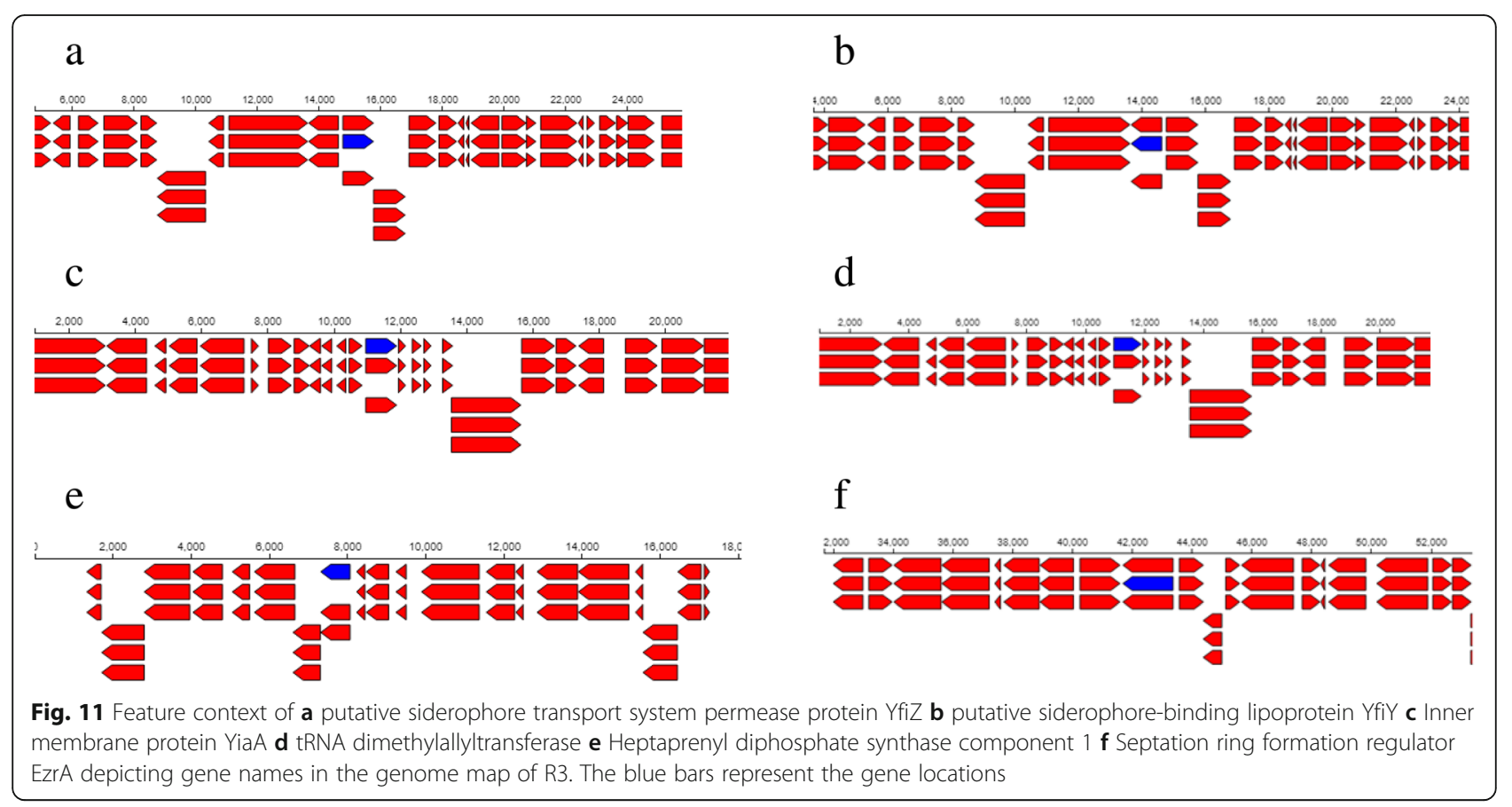

(Table 4) and the locations of the respective genes were between 536 and 704 for the R1 strain (Fig. 9c, d) and between contigs 11,701-11,965 and 10,955-11,900 for the R3 strain (Fig. 11c, d).

Based on the results of the growth response to different environmental pH, R1 and R3 strains can be considered acid-tolerant strains since they were able to survive and grow at a low $\mathrm{pH}$ of 4 . Again, upon application in the field, these strains may be confronted with acid stress in acidic soils and within the symbiosome. According to [1], the mechanisms involved in rhizobial survival and growth in acidic environments are yet to be understood. EptA genes coding for UDP-Nacetylmuramate-L-alanyl-gamma-D-glutamyl-meso-2,6diaminoheptandioate ligase and Phosphoethanolamine transferase were found in R1 strains. [1] also found genes in R. tropici CIAT 899 and Rhizobium sp. PRF 81 coding for 'putative lipid A Phosphoethanolamine transferase' similar to that found in R1 strain in this study. In Salmonella typhimurium and Escherichia coli, eptA gene is activated under mildly acidic environments and it was reported that eptA imposed acid tolerance in Shigella flexneri 2a [67]. Also, eptA genes were reported in $R$. rhizogenes K84, sinorhizobia, agrobacteria, but not in other Rhizobium spp. [1].

\section{Conclusions}

It was found that Rhizobium sp. strain R1, Rhizobium tropici strain R2, Rhizobium cellulosilyticum strain R3, Rhizobium taibaishanense strain R4 and Ensifer meliloti strain R5 isolated from Bambara groundnut rhizosphere possess the PGP traits considered in this study. In particular, these rhizobial strains produced EPS, ACC and in addition were able to survive and grow at a temperature of $45^{\circ} \mathrm{C}$ and in an acidic condition with a $\mathrm{pH}$ of 4 . Consequently, R1, R3 and R5 strains enhanced the germination of soybean seeds (PAN $1532 \mathrm{R}$ ) under drought condition imposed by $4 \%$ PEG; nevertheless, Rhizobium sp. strain R1 and R. cellulosilyticum strain R3 inoculations were able to improve seeds germination more than R5. Thus, genomic insights into Rhizobium sp. strain R1 and R. cellulosilyticum strain R3 revealed the presence of some genes with their respective proteins involved in symbiotic establishment, drought tolerance and plant growth promotion. In particular, exoX, htrA, Nif, nodA, eptA, IAA and siderophore-producing genes were found in the two rhizobial strains. Therefore, the possible PGP ability of these rhizobial strains can further be harnessed for biotechnological application in the field especially in semiarid and arid regions of the globe.

\footnotetext{
Abbreviations

ACC: 1-aminocyclopropane-1-carboxylate; ACS: Aminocyclopropane-1carboxylate synthase; ANOVA: Analysis of Variance; BLAST: Basic Local Alignment Search Tool; CAS: Chrome azurol S; CFU: Coliform forming unit; DNA: Deoxyribonucleic acid; EPS: Exopolysaccharide; GC: Guanine cytosine; HSPs: Heat shock proteins; IAA: Indole-acetic-acid; KEGG: Kyoto encyclopedia of genes and genomes; LB: Luria Bertani; NCBI: National Centre for Biotechnology Information; O.D: Optical density; PCR: Polymerase chain reaction; PEG: Polyethylene glycol; PGP: Plant growth promoting; R1: Rhizobium sp. strain R1; R2: Rhizobium tropici strain R2; R3: Rhizobium cellulosilyticum strain R3; R4: Rhizobium taibaishanense strain R4; R5: Ensifer meliloti strain R5; RAST: rapid annotation using subsystem technology; rpm: Revolution per minute; SAS: Statistical Analysis System; SE: Standard error
}

Acknowledgements Not applicable. 


\section{Authors' contributions}

INO designed and performed the experiment and wrote the article; BOO secured funding, provided academic input in writing the manuscript and thoroughly critiqued the article while INO and ABR did bioinformatics analyses of the genomic data. All authors approved the article for publication.

\section{Funding}

This work was financially supported by National Research Foundation, South Africa/ The World Academy of Science African Renaissancee grant (UID105466) and National Research Foundation, South Africa grants (UID81192, UID99779, UID95111, and UID104015).

\section{Availability of data and materials}

The data for R1 strain are available in NCBI database under Bioproject number PRJNA496421, Biosample number SAMN10240937, SRA Accession number SRR8060784. Similarly data for R3 strain are available in NCBI database under Bioproject number PRJNA496421, Biosample number SAMN10245972, SRA Accession number SRR8061690.

\section{Ethics approval and consent to participate}

This article does not contain any studies with human participants or animals performed by any of the authors.

\section{Consent for publication}

Not applicable.

\section{Competing interests}

The authors declare that they have no competing interests.

Received: 15 November 2018 Accepted: 30 June 2019

Published online: 11 July 2019

\section{References}

1. Ormeño-Orrillo E, Menna P, Almeida LGP, Ollero FJ, Nicolás MF, Rodrigues $E P$, et al. Genomic basis of broad host range and environmental adaptability of Rhizobium tropici CIAT 899 and Rhizobium sp. PRF 81 which are used in inoculants for common bean (Phaseolus vulgaris L.). BMC Genomics. 2012; 13:735

2. Igiehon NO, Babalola OO. Rhizosphere microbiome modulators: contributions of nitrogen fixing Bacteria towards sustainable agriculture. Environ Res Public Health. 2018;15:574.

3. Grover M, Ali SZ, Sandhya V, Rasul A, Venkateswarlu B. Role of microorganisms in adaptation of agriculture crops to abiotic stresses. World J Microbiol Biotechnol. 2011;27:1231-40.

4. Yang J, Kloepper JW, Ryu C-M. Rhizosphere bacteria help plants tolerate abiotic stress. Trends Plant Sci. 2009:14:1-4.

5. Dimkpa C, Weinand T, Asch F. Plant-rhizobacteria interactions alleviate abiotic stress conditions. Plant Cell Environ. 2009:32:1682-94.

6. Maheshwari DK. Bacteria in agrobiology: crop system. Heidelberg: Springer; 2011.

7. Kim Y-C, Glick BR, Bashan Y, Ryu C-M. Enhancement of plant drought tolerance by microbes. In: Plant responses to drought stress. Berlin, Heidelberge: Springer-Verlag; 2012. p. 383-413.

8. Hardoim PR, van Overbeek LS, van Elsas JD. Properties of bacterial endophytes and their proposed role in plant growth. Trends Microbiol. 2008;16:463-71.

9. Glick BR. Modulation of plant ethylene levels by the bacterial enzyme ACC deaminase. FEMS Microbiol Lett. 2005;251:1-7.

10. Sharma P, Khanna V, Kumari P. Efficacy of aminocyclopropane-1-carboxylic acid (ACC)-deaminase-producing rhizobacteria in ameliorating water stress in chickpea under axenic conditions. Afr J Microbiol Res. 2013;7:5749-57.

11. Roberson EB, Firestone MK. Relationship between desiccation and exopolysaccharide production in a soil Pseudomonas sp. Appl Environ Microbiol. 1992:58:1284-91.

12. Mantelin S, Touraine B. Plant growth-promoting bacteria and nitrate availability: impacts on root development and nitrate uptake. J Exp Bot. 2004;55:27-34

13. Pérez-Montaño F, Alías-Villegas C, Bellogín R, Del Cerro P, Espuny M, Jiménez-Guerrero I, et al. Plant growth promotion in cereal and leguminous agricultural important plants: from microorganism capacities to crop production. Microbiol Res. 2014;169:325-36.

14. Tkacz A, Poole P. Role of root microbiota in plant productivity. J Exp Bot 2015:66:2167-75.

15. Bar-Ness E, Chen Y, Hadar Y, Marschner H, Römheld V. Siderophores of Pseudomonas putida as an iron source for dicot and monocot plants. Plant Soil. 1991;130:231-41.

16. Traxler MF, Seyedsayamdost MR, Clardy J, Kolter R. Interspecies modulation of bacterial development through iron competition and siderophore piracy. Mol Microbiol. 2012;86:628-44.

17. Bal HB, Das S, Dangar TK, Adhya TK. ACC deaminase and IAA producing growth promoting bacteria from the rhizosphere soil of tropical rice plants. J Basic Microbiol. 2013:53:972-84.

18. Ahmad F, Ahmad I, Khan M. Screening of free-living rhizospheric bacteria for their multiple plant growth promoting activities. Microbiol Res. 2008;163: 173-81.

19. Mohite B. Isolation and characterization of indole acetic acid (IAA) producing bacteria from rhizospheric soil and its effect on plant growth. $J$ Soil Sci Plant Nutr. 2013;13:638-49.

20. Masciarelli O, Llanes A, Luna V. A new PGPR co-inoculated with Bradyrhizobium japonicum enhances soybean nodulation. Microbiol Res. 2014;169:609-15.

21. Hungria M, Stacey G. Molecular signals exchanged between host plants and rhizobia: basic aspects and potential application in agriculture. Soil Biol Biochem. 1997;29:819-30.

22. Oldroyd GE, Downie JA. Coordinating nodule morphogenesis with rhizobial infection in legumes. Annu Rev Plant Biol. 2008:59:519-46.

23. Perret X, Staehelin C, Broughton WJ. Molecular basis of symbiotic promiscuity. Microbiol Mol Biol Rev. 2000;64:180-201.

24. Fauvart M, Michiels J. Rhizobial secreted proteins as determinants of host specificity in the Rhizobium-legume symbiosis. FEMS Microbiol Lett. 2008:285:1-9.

25. Ali SZ, Sandhya V, Rao LV. Isolation and characterization of drought-tolerant ACC deaminase and exopolysaccharide-producing fluorescent Pseudomonas sp. Ann Microbiol. 2014;64:493-502

26. Paulo EM, Vasconcelos MP, Oliveira IS, Affe HMJ, Nascimento R, ISd M, et al. An alternative method for screening lactic acid bacteria for the production of exopolysaccharides with rapid confirmation. Food Sci Technol. 2012;32: $710-4$.

27. Putrie RFW, Wahyudi AT, Nawangsih AA, Husen E. Screening of rhizobacteria for plant growth promotion and their tolerance to drought stress. Microbiol Indones. 2013:7:2

28. Sasirekha B, Srividya S. Siderophore production by Pseudomonas aeruginosa FP6, a biocontrol strain for Rhizoctonia solani and Colletotrichum gloeosporioides causing diseases in chilli. Agric Nat Resour. 2016;50:250-6.

29. Gaur A. Phosphate solubilizing micro-organisms as biofertilizer. New Delhi: Omega scientific publishers; 1990. p. 16-72.

30. Prakamhang J, Tittabutr P, Boonkerd N, Teamtisong K, Uchiumi T, Abe M, et al. Proposed some interactions at molecular level of PGPR coinoculated with Bradyrhizobium diazoefficiens USDA1 10 and B. japonicum THA6 on soybean symbiosis and its potential of field application. Appl Soil Ecol. 2015; 85:38-49.

31. Bolger AM, Lohse M, Usadel B. Trimmomatic: a flexible trimmer for Illumina sequence data. Bioinformatics. 2014;30:2114-20.

32. Aziz RK, Bartels D, Best AA, DeJongh M, Disz T, Edwards RA, et al. The RAST server: rapid annotations using subsystems technology. BMC Genomics. 2008:9:75.

33. Igiehon NO. Bioremediation potentials of Heterobasidion annosum $13.12 \mathrm{~B}$ and Resinicium bicolor in diesel oil contaminated soil microcosms. J Appl Sci Environ Manag. 2015;19:513-9.

34. Dytham C. Choosing and using statistics: a biologist's guide. 3rd ed. West Sussex: Wiley; 2011.

35. Arshad M, Shaharoona B, Mahmood T. Inoculation with Pseudomonas spp containing ACC-deaminase partially eliminates the effects of drought stress on growth, yield, and ripening of pea (Pisum sativum L.). Pedosphere. 2008; 18:611-20.

36. Ozturk S, Aslim B. Modification of exopolysaccharide composition and production by three cyanobacterial isolates under salt stress. Environ Sci Pollut Res. 2010;17:595-602.

37. Sayyed R, Badqujar M, Sonawane $H$, Mhaske M, Chincholkar S. Production of microbial iron chelators (siderophores) by fluorescent Pseudomonads; 2005. 
38. Omidvari M, Sharifi RA, Ahmadzadeh M, Dahaji PA. Role of fluorescent pseudomonads siderophore to increase bean growth factors. J Agric Sci. 2010;2:242.

39. Sarwar $M$, Kremer R. Determination of bacterially derived auxins using a microplate method. Lett Appl Microbiol. 1995;20:282-5.

40. Zhang F, Lynch DH, Smith DL. Impact of low root temperatures in soybean [Glycine max.(L.) Merr.] on nodulation and nitrogen fixation. Environ Exp Bot. 1995;35:279-85.

41. Alexandre A, Oliveira S. Response to temperature stress in rhizobia. Crit Rev Microbiol. 2013;39:219-28.

42. Chen L, Figueredo A, Villani H, Michajluk J, Hungria M. Diversity and symbiotic effectiveness of rhizobia isolated from field-grown soybean nodules in Paraguay. Biol Fertil Soils. 2002;35:448-57.

43. Karanja NK, Wood M. SelectingRhizobium phaseoli strains for use with beans (Phaseolus vulgaris L.) in Kenya: tolerance of high temperature and antibiotic resistance. Plant Soil. 1988;112:15-22.

44. Abd-Alla MH, El-Enany A-WE, Nafady NA, Khalaf DM, Morsy FM. Synergistic interaction of Rhizobium leguminosarum bv. Viciae and arbuscular mycorrhizal fungi as a plant growth promoting biofertilizers for faba bean (Vicia faba L.) in alkaline soil. Microbiol Res. 2014;169:49-58.

45. Jalili F, Khavazi K, Pazira E, Nejati A, Rahmani HA, Sadaghiani HR, et al. Isolation and characterization of ACC deaminase-producing fluorescent pseudomonads, to alleviate salinity stress on canola (Brassica napus L.) growth. J Plant Physiol. 2009;166:667-74.

46. Yuan Z-C, Liu P, Saenkham P, Kerr K, Nester EW. Transcriptome profiling and functional analysis of Agrobacterium tumefaciens reveals a general conserved response to acidic conditions (pH 5.5) and a complex acidmediated signaling involved in Agrobacterium-plant interactions. J Bacteriol. 2008;190:494-507.

47. Hellweg C, Pühler A, Weidner S. The time course of the transcriptomic response of Sinorhizobium meliloti 1021 following a shift to acidic pH. BMC Microbiol. 2009:9:37.

48. Cunningham SD, Munns DN. The correlation between extracellular polysaccharide production and acid tolerance in Rhizobium 1. Soil Sci Soc Am J. 1984:48:1273-6.

49. Becker A, Fraysse N, Sharypova L. Recent advances in studies on structure and symbiosis-related function of rhizobial K-antigens and lipopolysaccharides. Mol Plant-Microbe Interact. 2005:18:899-905.

50. Skorupska A, Janczarek M, Marczak M, Mazur A, Król J. Rhizobial exopolysaccharides: genetic control and symbiotic functions. Microb Cell Factories. 2006;5:7

51. Ormeño-Orrillo E, Rosenblueth M, Luyten E, Vanderleyden J, MartínezRomero E. Mutations in lipopolysaccharide biosynthetic genes impair maize rhizosphere and root colonization of Rhizobium tropici CIAT899. Environ Microbiol. 2008;10:1271-84

52. D'Haeze W, Holsters M. Surface polysaccharides enable bacteria to evade plant immunity. Trends Microbiol. 2004;12:555-61.

53. Ingram BO, Sohlenkamp C, Geiger O, Raetz CR. Altered lipid a structures and polymyxin hypersensitivity of Rhizobium etli mutants lacking the LpxE and LpxF phosphatases. Biochim Biophys Acta Mol Cell Biol Lipids. 2010;1801:593-604.

54. Zhan H, Leigh JA. Two genes that regulate exopolysaccharide production in Rhizobium meliloti. J Bacteriol. 1990;172:5254-9.

55. Martínez-Romero E, Segovia L, Mercante FM, Franco AA, Graham P, Pardo MA. Rhizobium tropici, a novel species nodulating Phaseolus vulgaris L. beans and Leucaena sp. trees. Int J Syst Evol Microbiol. 1991:41:417-26.

56. Hungria M, de S Andrade D, de O Chueire LM, Probanza A, GuttierrezMañero FJ, Megías M. Isolation and characterization of new efficient and competitive bean (Phaseolus vulgaris L.) rhizobia from Brazil. Soil Biol Biochem. 2000;32:1515-28.

57. Clausen T, Southan C, Ehrmann M. The HtrA family of proteases: implications for protein composition and cell fate. Mol Cell. 2002;10:443-55.

58. Glazebrook J, Ichige A, Walker GC. Genetic analysis of Rhizobium meliloti bacA-phoA fusion results in identification of degP: two loci required for symbiosis are closely linked to degP. J Bacteriol. 1996;178:745-52.

59. Phillips RW, Roop RM. Brucella abortus HtrA functions as an authentic stress response protease but is not required for wild-type virulence in BALB/C mice. Infect Immun. 2001;69:5911-3.

60. Nogales J, Campos R, BenAbdelkhalek H, Olivares J, Lluch C, Sanjuan J. Rhizobium tropici genes involved in free-living salt tolerance are required for the establishment of efficient nitrogen-fixing symbiosis with Phaseolus vulgaris. Mol Plant-Microbe Interact. 2002;15:225-32.
61. Schwartz CJ, Djaman O, Imlay JA, Kiley PJ. The cysteine desulfurase, IscS, has a major role in in vivo Fe-S cluster formation in Escherichia coli. Proc Natl Acad Sci. 2000;97:9009-14.

62. Dean DR, Bolin JT, Zheng L. Nitrogenase metalloclusters: structures, organization, and synthesis. J Bacteriol. 1993;175:6737.

63. Zheng L, White RH, Cash VL, Dean DR. Mechanism for the desulfurization of Lcysteine catalyzed by the nifS gene product. Biochemistry. 1994;33:4714-20.

64. Debellé F, Plazanet C, Roche P, Pujol C, Savagnac A, Rosenberg C, et al. The NodA proteins of Rhizobium meliloti and Rhizobium tropici specify the Nacylation of nod factors by different fatty acids. Mol Microbiol. 1996;22:303-14.

65. Hungria M, Nogueira MA, Araujo RS. Co-inoculation of soybeans and common beans with rhizobia and azospirilla: strategies to improve sustainability, Biol Fertil Soils. 2013:49:791-801.

66. Igiehon NO, Babalola OO. Below-ground-above-ground plant-microbial interactions: focusing on soybean, Rhizobacteria and mycorrhizal Fungi. Open Microbiol J. 2018;12:261-79.

67. Martinić M, Hoare A, Contreras I, Álvarez SA. Contribution of the lipopolysaccharide to resistance of Shigella flexneri 2a to extreme acidity. PLoS One. 2011;6:e25557.

\section{Publisher's Note}

Springer Nature remains neutral with regard to jurisdictional claims in published maps and institutional affiliations.
Ready to submit your research? Choose BMC and benefit from:

- fast, convenient online submission

- thorough peer review by experienced researchers in your field

- rapid publication on acceptance

- support for research data, including large and complex data types

- gold Open Access which fosters wider collaboration and increased citations

- maximum visibility for your research: over $100 \mathrm{M}$ website views per year

At BMC, research is always in progress.

Learn more biomedcentral.com/submissions 